
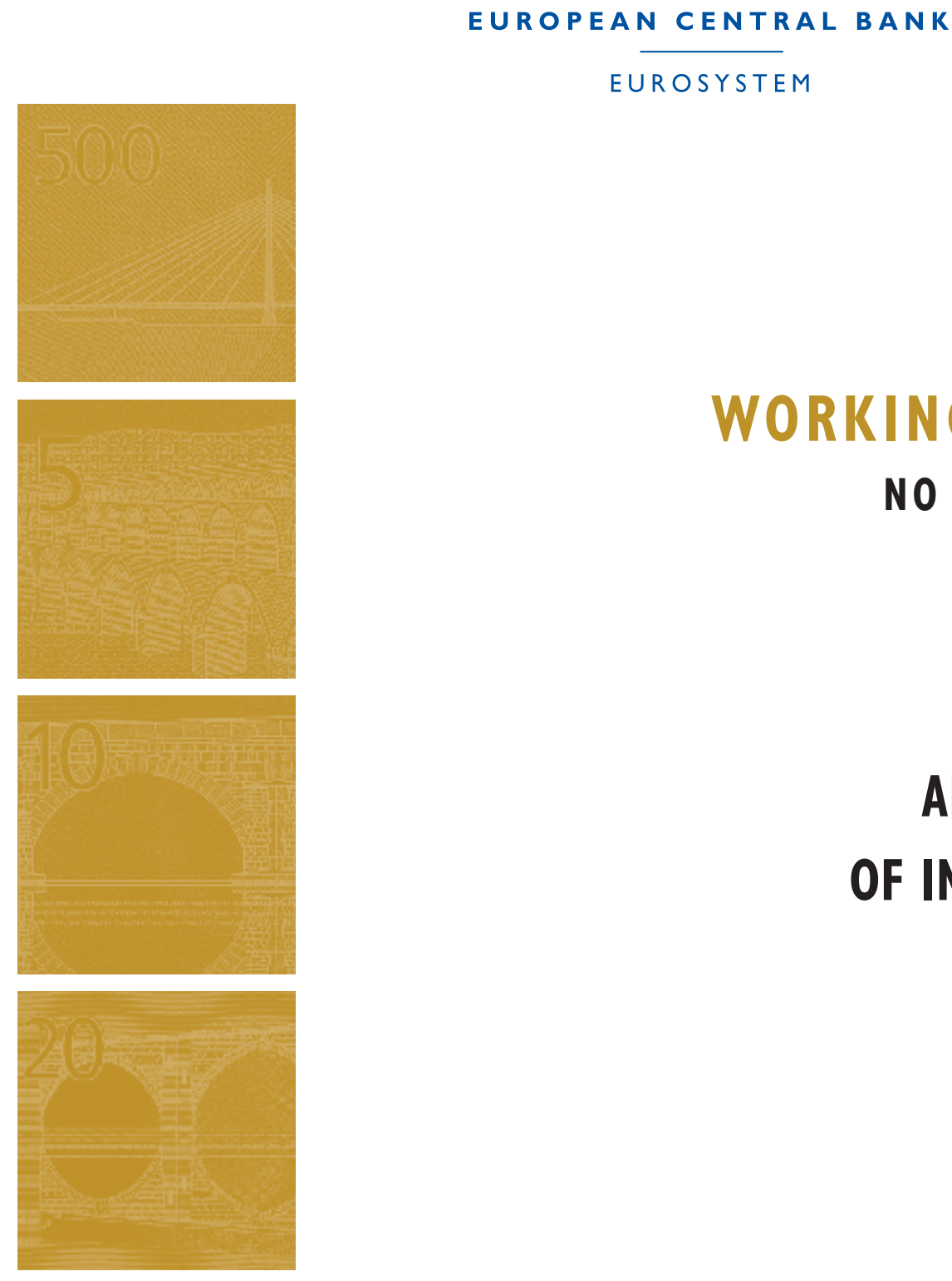

In 2012 all ECB

publications

eature a motif the $€ 50$ banknote.

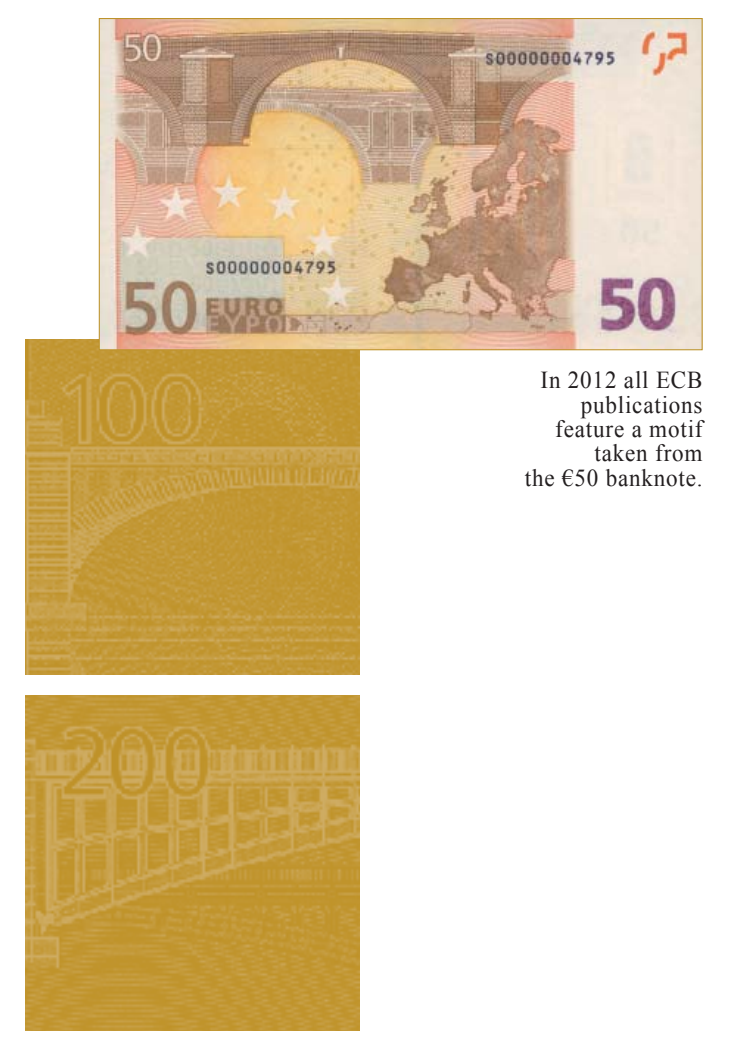

\section{HAS THE EURO AFFECTED THE CHOICE
OF INVOICING CURRENCY? AFFECTED THE CHOICE
OF INVOICING CURRENCY?}

by Jenny E. Ligthart and Sebastian E. V. Werner

by Jeny E. Ligth

NOTE: This Working Paper should not be reported as representing the views of the European Central Bank (ECB). The views expressed are those of the authors and do not necessarily reflect those of the ECB. 


\section{Acknowledgements}

This paper is a substantially revised version of CentER Discussion Paper No. 2010-48. This paper was revised during the second author's stay at the European Central Bank. The authors would like to thank Ronny Haugan of Statistics Norway for providing the invoicing data and Kamilla Austnes of Statistics Norway for supplying the data on the commodity composition of Norwegian trade. We are also grateful to three anonymous referees, Martin Brown, Cecile Couharde, Charles Engel, Richard Friberg, Joseph Gagnon, Jean-Yves Gnabo, Jean Imbs, Jan Jacobs, Michael Kumhof, Chuck Manski, Kenneth Train, Casper de Vries, and conference participants at the 8th annual conference of the Irish Society of New Economists (Dublin, August 2011), the 28th GdRE International Annual Symposium on Money, Banking, and Finance (Reading, June 2011), the 15th International Conference on Macroeconomic Analysis and International Finance (Crete, May 2011), the 4th Italian Congress of Econometrics and Empirical Economics (Pisa, February 2011), and the annual conference of the Netherlands Network of Economics (Utrecht, April 2010) for helpful discussions and comments.

\section{Jenny E. Ligthart (corresponding author)}

at CentER and Department of Economics, Tilburg University, P.O. Box 90153, 5000 LE Tilburg, The Netherlands; e-mail: j.ligthart@tilburguniversity.edu

\section{Sebastian E. V. Werner}

at Tilburg University, Warandelaan 2, 5037 AB Tilburg, The Netherlands; e-mail: sebwern@gmx.de

(C) European Central Bank, 2012

\section{Address}

Kaiserstrasse 29, 60311 Frankfurt am Main, Germany

Postal address

Postfach 1603 19, 60066 Frankfurt am Main, Germany

\section{Telephone}

+496913440

\section{Internet}

http://www.ecb.europa.eu

\section{Fax}

+496913446000

All rights reserved.

ISSN 1725-2806 (online)

Any reproduction, publication and reprint in the form of a different publication, whether printed or produced electronically, in whole or in part, is permitted only with the explicit written authorisation of the ECB or the authors.

This paper can be downloaded without charge from http://www.ecb.europa.eu or from the Social Science Research Network electronic library at http://ssrn.com/abstract_id=1765350.

Information on all of the papers published in the ECB Working Paper Series can be found on the ECB's website, http://www.ecb.europa. eu/pub/scientific/wps/date/html/index.en.html 


\begin{abstract}
We present a new approach to study empirically the effect of the introduction of the euro on the pattern of currency invoicing. Our approach uses a compositional multinomial logit model, in which currency choice is explained by both currency-specific and countryspecific determinants. We use unique quarterly panel data on the invoicing of Norwegian imports from OECD countries for the 1996-2006 period. We find that eurozone countries have substantially increased their share of home currency invoicing after the introduction of the euro, whereas the home currency share of non-eurozone countries fell slightly. In addition, the euro as a vehicle currency has overtaken the role of the US dollar in Norwegian imports. The substantial rise in producer currency invoicing by eurozone countries is primarily caused by a drop in inflation volatility and can only to a small extent be explained by an unobserved euro effect.
\end{abstract}

JEL codes: F33, F41, F42, E31, C25

Keywords: euro, invoicing currency, exchange rate risk, inflation volatility, vehicle currencies, compositional multinomial logit 


\section{Non-Technical Summary}

Currency invoicing of international goods trade has interested academics and policy makers as early as the 1970s when the Bretton Woods system of fixed but adjustable exchange rates collapsed and the main trading countries in the world moved to flexible exchange rates. The introduction of the euro in non-cash form (i.e., electronic transfers, banking, etcetera) on January 1, 1999 and in cash form on January 1, 2002 has brought currency invoicing to the fore. Informal evidence points to a substantial impact of the euro on traders' choice of invoicing currency. Little formal evidence on the euro's effect on currency invoicing exists. A notable exception is the work by Kamps (2006). This paper studies whether the euro has affected the choice of invoicing currency.

At first sight, the answer to our research question seems an obvious 'yes' given that the euro did not exist prior to 1999. However, we are interested in measuring whether the euro has had an effect on the home currency share of eurozone exporters (so-called producer currency invoicing) above and beyond their home currency share prior to euro introduction. In addition, we measure the euro's effect on the share of the importer's home currency and the shares of the respective vehicle currencies (which refer to any third currency used in a bilateral trading relationship). To this end, we use an invoicing data set covering Norwegian goods imports from OECD countries during the 1996-2006 period. We have chosen Norway because it: (i) is not part of the eurozone; and (ii) obtains almost 40 percent of its imports from eurozone countries. The data span allows us to examine invoicing patterns before, during transition, and after the introduction of the euro.

So far, the empirical invoicing literature has only used explanatory variables related to the partner countries in trade (so-called country-specific variables). This paper introduces a new approach that relates explanatory variables to the currencies (so-called currency-specific variables). More specifically, the new approach makes it possible to relate traders' invoicing motives directly to the currency attributes, that is, a euro dummy, a euro transition dummy, exchange rate volatility of the chosen currency with respect to the local currency (Norwegian krone), exchange rate volatility of the chosen currency with respect to the partner currency, 
and the depth of the currency's foreign exchange market.

The descriptive analysis shows a substantial change in invoicing patterns induced by euro introduction. Norway's trading partners participating in the eurozone use their own currency (i.e., the euro) more frequently than before the introduction of the euro. Compared to the non-eurozone control group, the producer currency invoicing share of eurozone countries rises on average by 32.6 percentage points after euro introduction. We also find that the euro is chosen more often as a vehicle currency than the US dollar. The share of the US dollar in vehicle currencies used in Norwegian imports drops from 52.7 percent in 1996 to 41.5 percent in 2006 .

The econometric analysis shows that above and beyond the control variables, the introduction of the euro has increased the share of producer currency invoicing by eurozone countries. However, the unobserved effect of euro introduction - e.g., trust in the common currency - is rather modest, that is, on average, we find a 2 percentage points rise in invoicing in producer currencies by eurozone countries. The increase in euro invoicing is primarily caused by a drop in inflation volatility induced by the process of monetary unification. The larger euro invoicing share in Norwegian imports has increased ceteris paribus Norway's trade account exposure to exchange rate changes. A depreciation of the Norwegian krone would lead to more 'imported inflation' and a larger trade deficit than before the introduction of the euro. 


\section{Introduction}

Currency invoicing of international goods trade has interested academics and policy makers as early as the 1970s when the Bretton Woods system of fixed but adjustable exchange rates collapsed and the principal trading countries in the world moved to flexible exchange rates. The introduction of the euro in non-cash form (i.e., electronic transfers, banking, etcetera) on January 1, 1999 and in cash form on January 1, 2002 ${ }^{1}$ has given a renewed impetus to the invoicing literature. ${ }^{2}$ The introduction of the euro is believed to have had a substantial impact on traders' choice of invoicing currency. More specifically, the euro would boost home currency invoicing by firms located in eurozone countries and euro use by non-eurozone exporters trading with eurozone countries. ${ }^{3}$ This paper empirically investigates whether a country's pattern of invoicing currency choice is affected by euro introduction.

Knowing which factors affect the pattern of invoicing is important on three accounts. The first reason is that invoicing patterns matter for how a country's trade balance responds to a change in its exchange rate. If countries' exports are fully invoiced in the exporter's currency (and thus imports are by definition invoiced in a foreign currency), a depreciation of the exporter's currency — given that trade contracts are given in the short run-would cause an initial worsening of the trade balance. ${ }^{4}$ Second, the choice of invoicing currency affects the degree to which import prices are affected by exchange rate movements, the so-called exchange rate "pass-through." Finally, from a microeconomic point of view, the choice of invoicing currency determines a firm's exposure to exchange risk. If a transaction is invoiced in any other currency than its own, a trading firm is exposed to exchange rate uncertainty, leading to revenue uncertainty.

\footnotetext{
${ }^{1}$ The euro was introduced on January 1, 1999 in Austria, Belgium, Finland, France, Germany, Ireland, Italy, Luxembourg, the Netherlands, Portugal, and Spain. Greece joined on January 1, 2001, bringing the total number of European Union (EU) member states adopting the euro (the so-called eurozone) to 12 countries. Nowadays, the eurozone consists of 17 countries.

${ }^{2}$ The 'New Open Economy Macroeconomics' literature based on Obstfeld and Rogoff's (1995) paper also contributed to this revival. See Section 2 for a further discussion.

${ }^{3}$ Bacchetta and Van Wincoop (2005) present a theoretical analysis, whereas Kamps (2006) and Goldberg and Tille (2008) provide empirical evidence.

${ }^{4}$ See Melvin and Sultan (1990) for an empirical study on the link between invoicing currency patterns and the impact of a currency depreciation on the balance of trade.

${ }^{5}$ In fact, Gopinath et al. (2010) provide empirical evidence that currency choice is crucial for understanding exchange rate pass-through. There is an extensive literature on exchange rate pass-through. Feenstra (1989) and Feenstra et al. (1996) are early contributions.
} 
Little is known empirically about the determinants of invoicing currency choice, let alone the effect of currency unions on invoicing patterns. The limited number of studies no doubt reflects the considerable confidentiality with which the invoicing data are treated by central banks and customs offices. Recently, a few econometric studies have studied invoicing determinants. ${ }^{6}$ Our work is most closely related to the unpublished study by Kamps (2006), who empirically assesses the effect of a country's eurozone membership on the invoicing share of the euro, the US dollar, and a country's home currency. To this end, she uses cross-country invoicing data at an annual frequency. Because of her focus on a single aggregate currency share in each equation, Kamps (2006) cannot analyze the effect of the euro on invoicing patterns, that is, the system of all currency shares. Furthermore, the annual frequency of her data in combination with the short time span of analysis makes it hard to separate the transition effect from the steady-state effect of euro introduction.

To investigate the effect of euro introduction on individual currencies and currency groups during the two stages of euro introduction, we use a unique invoicing data set for Norway. We have chosen Norway because it is not part of the eurozone, which allows the study of the effect of the euro on partner currency use in Norwegian imports from eurozone countries and on vehicle currency invoicing in Norwegian imports from countries outside the eurozone. ${ }^{7}$ Furthermore, with Germany as its second most important trading partner, Norway obtains almost 40 percent of its imports from eurozone countries. The data consist of the value of Norwegian (non-oil) goods imports broken down by country and currency for the period 1996-2006 and are measured at a quarterly frequency. These data are used to derive bilateral currency shares for all the currencies of OECD countries. The econometric analysis includes 29 OECD countries, roughly capturing 85 percent of Norwegian imports. ${ }^{8}$ The invoicing data used in this study span the period prior to euro introduction, the transition period 1999-2001

\footnotetext{
${ }^{6}$ Donnenfeld and Haug (2003), Wilander (2006), Fischer et al. (2007), Ligthart and Da Silva (2007), Donnenfeld and Haug (2008), Friberg and Wilander (2008), Ito et al. (2010), and Goldberg and Tille (2011) study the invoicing determinants using data for a single country. Kamps (2006) and Goldberg and Tille (2008) employ aggregate cross-country invoicing data. See Section 2 for a further discussion.

${ }^{7} \mathrm{~A}$ 'vehicle currency' or 'third currency' is neither the currency of the exporter nor that of the importer in a trade transaction. We will use the terminology vehicle currency and third currency interchangeably.

${ }^{8}$ Because we focus on industrialized countries, we do not include large emerging economies, such as Brazil, Russia, India, and China. Note that the share of these four countries in Norwegian imports is negligible (about 7 percent). Furthermore, restricting our sample to OECD countries prevents large data gaps, which may bias our results.
} 
(when both the euro and national legacy currencies could be used in trade), and a sufficiently large post-transition period. ${ }^{9}$

We employ a compositional multinomial logit approach that weights the probability of traders choosing a particular currency by the respective currency share. This approach is appropriate because we have compositional data, that is, the currency shares lie in the closed unit interval $[0,1]$, add up to unity for a particular country at one point in time, and are correlated. ${ }^{10}$ Our analysis incorporates the characteristics of 31 currencies and thus goes beyond just characterizing the determinants of a single currency share. Hence, we are able to capture substitution effects between currencies due to euro introduction. We employ a euro dummy for the time period 1999Q1-2006Q4 to capture an unobserved euro effect (e.g., more trust in the common currency). In addition, a euro control dummy is introduced to describe legacy currency invoicing during the transition period. Finally, we employ both fixed effects and pooled models, where the former specification controls for unobserved heterogeneity across countries.

So far, the empirical invoicing literature has only used explanatory variables related to the partner countries in trade. These so-called country-specific variables do not vary across currencies. For example, a country's share in world trade and the share of differentiated products in the partner country's export package. This study introduces a new approach that relates covariates to the currencies, thereby introducing currency-specific variables (e.g., the size of the foreign exchange market) in addition to allowing country-specific covariates. Because we control for currency-specific determinants, we refer to a conditional compositional multinomial logit model. ${ }^{11}$ More specifically, our approach makes it possible to relate traders' invoicing motives directly to the currency attributes, that is, a euro dummy, a euro transition dummy, exchange rate volatility of the chosen currency with respect to the local currency (the Norwegian krone, NOK), exchange rate volatility of the chosen currency with respect to the partner currency, and the depth of the currency's foreign exchange market. Besides

\footnotetext{
${ }^{9}$ Legacy currencies are the currencies of the eurozone members that ceased to exist at the end of the transition period toward euro introduction.

${ }^{10} \mathrm{~A}$ simple logistic transformation cannot be employed in this case. See Section 4 for a further discussion.

${ }^{11}$ The discrete choice literature usually refers to the distinction between country-specific and currency-specific regressors as 'alternative-invariant' and 'alternative-varying' regressors, respectively.
} 
these methodological extensions, the paper also contributes to the invoicing literature more generally by considering a broader set of covariates (including inflation volatility) than has been studied before and by deriving average marginal effects in the context of a nonlinear invoicing model. ${ }^{12}$

We find in the descriptive analysis that Norway's trading partners participating in the eurozone use their own currency more frequently than before the introduction of the euro, whereas non-eurozone partners invoice less frequently in their home currency. However, the rise in the producer currency share of eurozone countries can only be partly attributed to a substitution from eurozone vehicle currencies to the euro. We also find that the euro is chosen more often as a vehicle currency than the US dollar. The econometric results for the fixed effects benchmark model show that above and beyond the control variables, the introduction of the euro has had a significant positive effect on the euro share. Euro introduction increases eurozone countries' share of producer currency invoicing (i.e., invoicing in the home currency by the exporter) by 2.6 percentage points. If the euro is chosen as a vehicle currency by non-eurozone countries its share rises by 3 percentage points. This unobserved euro effect only materialized gradually, reflecting the three-year transition phase and hysteresis in invoicing practices. We further find that the substantial rise in producer currency invoicing by eurozone countries is primarily caused by a drop in inflation volatility and can only to a small extent be explained by an unobserved euro effect. In the pooled model, invoicing in producer currencies increases if the size of the foreign exchange market is large, the degree of product differentiation is small, and the rate of inflation is low. The world trade share of a country is only significantly positive in a pooled model with country-specific variables.

This paper is organized as follows. Section 2 reviews the related literature. Section 3 derives various currency shares and describes invoicing patterns in Norwegian imports using currency share data. Section 4 discusses the econometric methodology. Section 5 presents the results on the invoicing effect of the euro while controlling for other determinants of invoicing currency choice. Finally, Section 6 concludes the paper.

\footnotetext{
${ }^{12}$ Previous invoicing studies that used nonlinear models have focused on the qualitative effects of a particular determinant rather than its quantitative impact.
} 


\section{Related Literature}

The theoretical literature on the invoicing effects of euro introduction-and monetary integration more generally - is rather small. Bacchetta and Van Wincoop's (2005) two-country general equilibrium model on invoicing currency choice is a notable exception. They hypothesize that if a set of countries form a monetary union they are more likely to invoice in the union's currency. Intuitively, if multiple countries adopt the same currency, the market share that matters is that of the entire currency union, not that of individual countries. The study of Devereux et al. (2004) deals with a potential indirect effect of monetary integration. They argue that exporters and importers will generally prefer to set prices in the currency of the country with a more stable monetary policy, as given by the variance of the relative money supplies.

The studies of Devereux et al. (2004) and Bacchetta and Van Wincoop (2005) build on the New Open Economy Macroeconomics literature, which is primarily initiated by the work of Obstfeld and Rogoff (1995). They developed a two-country general equilibrium model of exchange rate determination, which is also known as the Redux model. Key features of this research line are monopolistic competition on goods and/or labor markets and sticky nominal prices pre-set in a particular currency. An important issue in this literature is in which currency prices are assumed to be sticky. The Redux model assumes producer currency pricing $(\mathrm{PCP})$, that is, exporters set prices in their home currency. Accordingly, there is complete exchange rate pass-through of prices of imported goods to prices of domestic goods, ensuring that purchasing power parity holds at all times. However, Betts and Devereux (2000) show that the expenditure-switching effect of a nominal exchange rate change under PCP breaks down if firms engage in local currency pricing (LCP), that is, exporters pre-set prices and invoice in the importer's currency. ${ }^{13}$ All these studies assume an exogenously given invoicing currency. Devereux et al. (2004) and Bacchetta and Van Wincoop (2005) are some of the few studies to endogenize the invoicing currency share.

Table 1 presents an overview of the econometric studies that investigate the determinants of invoicing currency choice. The majority of studies employ aggregate invoicing data in the

\footnotetext{
${ }^{13}$ Krugman (1987) was one of the first authors to point out that foreign firms price locally.
} 
form of currency shares (labeled A in column (4) of the table), which are either bilateral currency shares for a single country or country-level shares in a cross-country setting (see column (3) of the table). Single-country studies based on aggregate share data have been conducted for Canada, the Netherlands, Sweden, and the United States. Kamps (2006) and Goldberg and Tille (2008) make use of aggregate cross-country invoicing data for a small sample of countries. The unpublished studies by Wilander (2006) and Goldberg and Tille (2011) are the only ones based on transaction-level invoicing data (labeled by $\mathrm{T}$ in the table). Fischer et al. (2007), Friberg and Wilander (2008), and Ito et al. (2010) employ survey data for Switzerland, Sweden, and Japan, respectively. Most of the studies show that a country's market power - measured in terms of a country's world export share or Gross Domestic Product (GDP) - leads to increased invoicing of its home currency. In addition, the degree of product differentiation negatively affects the use of vehicle currencies. Using invoicing data for the Netherlands, Ligthart and Da Silva (2007) find home currency invoicing to be positively affected by the rate of inflation in the partner country and negatively affected by the degree of development of the partner country's banking sector. They also find that EU countries invoice less in vehicle currencies as is also found by Wilander (2006). Fischer et al. (2007) and Friberg and Wilander (2008) emphasize the role of firm size; small exporting firms are more likely to use their home currency.

The study by Kamps (2006) is the only one that empirically assesses the effect of euro introduction on currency invoicing. She regresses both the euro and US dollar share on a set of explanatory variables in separate regression equations. She additionally analyzes a country's home currency share in exports and imports. Her analysis covers 42 countries and uses annual data for the 1994-2004 period. ${ }^{14}$ Kamps finds that the introduction of the euro and a country being a member of the EU or an EU accession candidate increases producer currency invoicing. In addition, the share of euro invoicing rises if a country pegs its currency to the euro, has a larger share of differentiated products in exports, trades more with the eurozone, and is an EU member. Countries' US dollar share in invoicing is negatively affected by their

\footnotetext{
${ }^{14}$ Her study is the first to put together a large cross-country data set. However, the data set is highly unbalanced, reflecting the scarcity of invoicing data at the cross-country level. Some countries have data covering the whole time period, whereas only individual years are observed for other countries. Only 19 of the 42 countries are included in the euro analysis.
} 
membership of the eurozone.

More remotely connected to our work are the studies by Wilander (2006) and Goldberg and Tille (2008). Wilander's (2006) analysis includes an Economic and Monetary Union (EMU) dummy, taking on the value of one if a country is an EMU member. However, his period of analysis covers 1999-2002 and thus does not capture the period before and after euro introduction. He finds that EMU membership increases the use of the local currency. Goldberg and Tille (2008) study vehicle currency invoicing by using the invoicing share of the US dollar and the euro as the respective dependent variables. Their analysis consists of 24 countries (including among others nine EU accession countries, Australia, Japan, and the United States) and uses annual observations for 1996-2003. They include an EU dummy and therefore cannot distinguish between eurozone and non-eurozone members. Goldberg and Tille (2008) find that the US dollar is predominantly used in countries' invoicing of goods trade with the United States and in the setting of prices of goods traded on organized exchanges. They also show that the euro is primarily employed as an invoicing currency by countries trading a substantial share of their goods with the EU.

\section{Invoicing Currency Shares}

This section defines various invoicing currency shares and provides a descriptive analysis of the currency shares in Norwegian goods imports.

\subsection{Currency Share Definitions}

Our analysis uses quarterly data on the aggregate value of Norwegian goods imports broken down by the currency of payment and the country of the trading partner for the 1996-2006 period. We include 29 OECD countries-i.e., all OECD member countries in 2006, excluding Norway - which covers roughly 85 percent of total Norwegian goods imports. The data used in this study have been collected by the Norwegian customs office. The Norwegian customs law requires traders to report all goods trade transactions of a value exceeding NOK 10,000 (euro 1,127). Besides the transaction value, transaction volume, and type of commodity, 
traders have to report the currency of payment. A small fraction of trade is censored by the reporting threshold; it does not exceed 5 percent in imports from any partner country and amounts to less than 3 percent of the aggregate import value. Because of confidentiality concerns, we do not have access to firm-level transactions. In addition, transactions in the oil and shipping sector - in which just a few large firms are active - are excluded from the reported data. Finally, we cannot observe the currency of invoicing. In the following, we assume that the currency of payment in any period is equal to the currency of invoicing. Friberg and Wilander (2008) point out that in more than 90 percent of the cases the two coincide.

In the econometric analysis of Section 4, we make use of invoicing currency shares, which are calculated as follows. Let us define $m_{j n t}$ to denote Norway's bilateral imports (which are measured in Norwegian krones) invoiced in currency $j=1, \ldots, J$ in trade with country $n=1, \ldots, N$ in quarter $t=1, \ldots, T$. Dividing $m_{j n t}$ by country $n$ 's exports to Norway at time $t$ - so that we correct for scale - we arrive at the currency share for currency $j$ in country $n$ at time $t$ :

$$
s_{j n t}=\frac{m_{j n t}}{\sum_{j=1}^{J} m_{j n t}}, \quad 0 \leq s_{j n t} \leq 1, \quad \sum_{j=1}^{J} s_{j n t}=1 .
$$

We have corrected $m_{j n t}$ for changes in the average exchange rate of the Norwegian krone with respect to each currency in the sample (Table A.1 in the Appendix). The $J$ currency shares represent compositional data; that is, the shares are bounded on the $[0,1]$ interval and add up to unity. In addition, the shares are not independent of each other because they have the same denominator; that is, $\operatorname{Cov}\left(s_{j n t}, s_{k n t}\right) \neq 0$ for any two currency shares $j$ and $k$ for $j \neq k$.

We distinguish a maximum of $J=31$ currencies and compute the corresponding bilateral currency shares. We focus only on currencies of OECD countries because no other currencies outside the OECD were actually chosen. Furthermore, it would be computationally demanding to distinguish all currencies in the world. Note that the set of currencies that is effectively available for use in the OECD area falls over time, reflecting the phasing out of currencies associated with euro introduction. During the 1996-1998 period, traders could use a maximum of 31 currencies, consisting of the currencies of OECD member countries and the European 
Currency Unit (ECU). For the 1999-2001 period, traders could potentially choose one of 30 currencies of the OECD member countries plus the euro. Finally, during the 2002-2006 period, 19 currencies are available; that is, all the currencies of OECD member countries, excluding the national legacy currencies and the ECU. Table A.2 shows the currency shares averaged over time and countries. The Norwegian krone, the euro, and the US dollar are the most frequently used. Out of 31 currencies five currencies are never chosen (i.e., the Hungarian forint, the Mexican peso, the Slovak koruna, the South Korean won, and the Turkish lira), but these will nevertheless be included in the econometric analysis of Sections 45 .

To permit a graphical analysis of the currency shares, we classify the currencies in three mutually exclusive groups. The first group is local currency invoicing (LCI), which refers to invoicing in the currency of the country where the exporter's goods are sold. In our case, the local currency is the Norwegian krone. The second group is called producer currency invoicing (PCI). For all partner countries that are not part of the eurozone, there is only one producer currency. Countries that are part of the eurozone have one producer currency until 1999 (i.e., their national currency), two producer currencies between 1999 and 2002 (i.e., their national legacy currency and the euro), and one producer currency from 2002 onwards (i.e., the euro). Finally, the third group is vehicle currency invoicing (VCI), which refers to invoicing of trade transactions in a third currency. The VCI group consists of all currencies excluding the Norwegian krone and the trading partner's currency. Using this currency grouping, we can calculate the respective currency group shares for country $n$ :

$$
s_{v n t}=\frac{m_{v n t}}{\sum_{v=1}^{V} m_{v n t}}, \quad m_{v n t}=\sum_{j=1}^{J_{v}} m_{j n t},
$$

where $m_{v n t}$ is the sum of Norway's imports from country $n$ invoiced in currencies belonging to group $v=1, \ldots, V$ (where $V=3$ corresponds to the three currency groups LCI, PCI, and VCI, respectively), $J_{v}$ is the number of currencies in group $v$, and $J=J_{\mathrm{LCI}}+J_{\mathrm{PCI}}+J_{\mathrm{VCI}}$.

The next step is to calculate the aggregate currency group shares, where we aggregate across countries. We take two approaches. The first approach corrects for trade value differences across countries. Norway's five biggest OECD trading partners make up more than 50 percent of its imports. To preclude that the invoicing of Norwegian imports from large trading 
partners overshadows that of smaller trading partners, we calculate equally-weighted currency group shares by averaging over the bilateral currency group shares: $s_{v t}^{E}=\frac{1}{N} \sum_{n=1}^{N} s_{v n t}$, where $s_{v n t}$ is defined in (2) and the label $E$ denotes equally-weighted currency group shares. The second approach calculates trade-weighted currency group shares (labeled by $T$ ) as follows: $s_{v t}^{T}=\frac{m_{v t}}{\sum_{v=1}^{V} \sum_{n=1}^{N} m_{v n t}}$, where $m_{v t}=\sum_{n=1}^{N} m_{v n t}$. The currency shares in Norwegian imports are analyzed in Section 3.2 .

\subsection{Descriptive Analysis}

Table 2 shows the bilateral currency shares for currency groups and the partner country's share in Norwegian imports. ${ }^{15}$ The PCI share varies substantially across countries, ranging from 0 to 75.3 percent. There is no clear link between the partner country's home currency share and its share in Norwegian imports. The home currency share of Norway's most important trading partner (Sweden) amounts to 45.9 percent, whereas that of its second most important trading partner (Germany) is 73.5 percent. In addition, although Poland is ranked as Norway's 15th largest trading partner, the share of the Polish Zloty is very small. More generally, many countries that joined the OECD in the second half of the 1990s have a negligible or zero PCI share.

Norway's five biggest trading partners - equally weighted - invoice on average 30 percent of their exports to Norway in the local currency (Norwegian krone), 55 percent in their home (producer) currency, and 15 percent in vehicle currencies. This invoicing pattern supports 'Grassman's law,' which says that trade between industrialized countries is mainly invoiced in the currency of the exporter. ${ }^{16}$ Averaged across all OECD countries and time periods, however, the invoicing of Norwegian imports looks quite different: 35.4 percent is invoiced in the Norwegian krone, 31.2 percent in producer currencies, and 33.3 percent in vehicle currencies.

Panel (a) of Figure 1 shows the average currency group shares of eurozone countries,

\footnotetext{
${ }^{15}$ Ligthart and Werner (2011) provide descriptive statistics for Norwegian exports.

${ }^{16}$ Grassman (1973) finds in his descriptive analysis of Swedish goods trade that two-thirds of exports to industrialized countries are invoiced in the producer's currency and a quarter are invoiced in the local currency. Because other authors found similar invoicing patterns, the invoicing literature refers to 'Grassman's law.' See Ligthart and Da Silva (2007) for further references.
} 
whereas Panel (b) presents the trade-weighted currency group shares. The introduction of the euro as a virtual currency in 1999 is indicated by the first dotted vertical line. The second dotted vertical line depicts the date of introduction of the euro in cash transactions in 2002, at which date the national currencies of the eurozone member states ceased to be legal tender. Panel (a) shows that the equally-weighted currency shares of eurozone countries have been affected considerably by the introduction of the euro. Before the introduction of the euro, imports from the eurozone are mainly invoiced in the Norwegian krone. Indeed, we can see that the average PCI share of 30 percent (denoted by the dashed line) is only slightly above that of vehicle currencies, implying a failure of Grassman's law. After the introduction of the euro in cash form, however, the PCI share rises substantially - reaching nearly 60 percent in 2003Q1 - and becomes dominant in 2001Q2. Hence, Grassman's law is supported after mid-2001. The the PCI share rises at the expense of the LCI and VCI shares (the solid and dotted lines, respectively).

Panel (b) of Figure 1 depicts that the trade-weighted currency group shares are in line with Grassman's law across the entire time period. In addition, the introduction of the euro seems to have also affected the trade-weighted currency shares, although the effects are less pronounced as for the case of equally-weighted currency shares. At the individual country level, we find the largest rise in the PCI share after euro introduction for Greece (52 percentage points), Luxembourg (50 percentage points), Spain (37.2 percentage points), and Portugal (34.7 percentage points), each of which have very small shares (less than 2 percent) in trade with Norway. ${ }^{17}$ However, the PCI share of Germany-which provides 16.4 percent of Norwegian imports from OECD countries — rises by less than 1 percentage point. Because Norway's smaller trading partners get a greater weight in the equally-weighted analysis than in the trade-weighted analysis, we find a larger euro effect for the former specification.

To investigate whether the rise in the PCI share has happened exclusively in the eurozone, we compare it to the PCI share of non-eurozone countries in our sample. Panels (c) and

\footnotetext{
${ }^{17}$ The figures are derived by comparing the average PCI share (expressed in percentages) during 1996-1999 period with that during the 2002-2006 period. Greece, Luxembourg, and Spain primarily switched away from vehicle currency use (VCI declined from 39.4 percent before 1999 to 7.1 percent after 2002), whereas Portugal mainly switched away from Norwegian krones (LCI dropped from 71.4 percent before 1999 to 50.6 percent after 2002).
} 
(d) of Figure 1 reveal that the PCI share of non-eurozone countries (the dashed line) falls slightly after the introduction of the euro, whereas the PCI share of eurozone countries rises substantially. Compared to the non-eurozone control group, the eurozone PCI share rises on average by 32.6 percentage points after euro introduction. ${ }^{18}$ One could argue that the rise in the PCI share primarily reflects a substitution from eurozone vehicle currencies to the euro. For instance, Norwegian imports from Italy that used to be invoiced in German marks - which counted toward VCI before euro introduction — are recorded as PCI after euro introduction. ${ }^{19}$ To get some idea about the potential size of this effect, we add the VCI share in Norwegian trade with eurozone countries to the PCI share (see the bullet pointed line). After January 1, 2002, the PCI share is still 10 percentage points higher than the bullet-pointed line, thereby providing support for a genuine euro effect.

Table 3 analyzes the composition of the trade-weighted vehicle currency share in Norwegian imports before and after euro introduction. We can see that the euro as a vehicle currency overtakes the US dollar after euro introduction. In 1996, the US dollar has the largest share (52 percent), followed by the German mark (27 percent). The share of all vehicle currencies belonging to the eurozone is 32 percent. The share of non-eurozone vehicle currencies (excluding the US dollar) accounts for 15.1 percent; it consists primarily of the currencies of Scandinavian partner countries (i.e., the Swedish krone and the Danish krone), together accounting for 12 percent. However, the share of the Pound sterling - once a major vehicle currency - is very small (2 percent). In 2006, the euro share amounts to 47.1 percent whereas the US dollar share (41.5 percent) falls below the euro share. The overall decrease of the VCI share in Norwegian imports partly reflects the introduction of the euro, which increases the PCI share in eurozone members. ${ }^{20}$ Panels (a) and (b) of Figure 2 illustrate the change in vehicle currency invoicing of Norwegian imports by non-eurozone countries (excluding the

\footnotetext{
${ }^{18}$ This figure is based on a simple difference-in-difference analysis. See Table A.9 of Ligthart and Werner (2011) for further details.

${ }^{19}$ Although substituting from eurozone vehicle currencies to the euro does appear to be the most natural move for traders, it should not be regarded as automatic and self-explanatory. Traders could also have substituted a eurozone vehicle currency for a vehicle currency outside the eurozone, such as the US dollar, if they were not convinced the euro to be as stable a currency as the German mark had been.

${ }^{20}$ Note that the average number of vehicle currencies used in Norwegian trade with eurozone countries dropped from 16 to 9 after euro introduction (compared to a drop from 15 to 9 in imports from non-eurozone members).
} 
United States) with a view to study vehicle currency invoicing outside the two monetary blocks. It shows how the euro share gradually increases during the transition period at the expense of the US dollar share. The share of other vehicle currencies remains rather stable (see the dotted line).

\section{Empirical Methodology}

This section sets out the empirical model used to analyze the determinants of currency invoicing. The econometric framework builds on and extends two strands of literature: (i) the discrete-choice literature on market share data (which is developed by Berry (1994) and applied by Nevo (2001) in the field of industrial organization); and (ii) the fractional response analysis of Papke and Wooldridge (1996). Our novel approach in the trade invoicing literature identifies country-specific and currency-specific variables separately, whereas the invoicing literature has exclusively focused on country-specific variables. In addition, our approach goes beyond Berry (1994) — who employs a logistic transformation of market shares - by taking into account that shares may lie at the extreme values of zero and one.

\subsection{Parameter Estimation}

A common starting point to model an agent's choice among alternatives is the random utility framework. In the context of invoicing, an optimizing exporter chooses the invoicing currency that gives the highest payoff in terms of utility. To facilitate the derivation of an estimating equation, we are assuming that the exporter in the partner country chooses the currency. ${ }^{21}$ More formally, we define the utility functional of trader $i=1, \ldots, I$ located in partner country $n=1, \ldots, N$ choosing currency $j \in\{1, \ldots, J\}$ in export to Norway in quarter $t=1, \ldots, T$ as follows:

$$
U_{i j n t}=\mathbf{z}_{j n t}^{\prime} \boldsymbol{\alpha}+\mathbf{x}_{n t}^{\prime} \boldsymbol{\beta}+\mathbf{d}_{n}^{\prime} \boldsymbol{\eta}+\xi_{i j n t},
$$

\footnotetext{
${ }^{21}$ Alternatively, we could have assumed that the Norwegian importer is choosing the currency. In practice, the currency choice is the result of bargaining between two trading parties. Viaene and De Vries (1992), Donnenfeld and Zilcha (1995), and Goldberg and Tille (2011) develop bargaining models to investigate the invoicing currency choice.
} 
where $\mathbf{z}_{j n t}^{\prime}$ is a $1 \times H_{z}$ row vector of explanatory variables related to currency $j=1, \ldots, J$ in each quarter $t, \mathbf{x}_{n t}^{\prime}$ is a $1 \times H_{x}$ row vector of explanatory variables pertaining to country $n$ in each quarter $t$, and $H_{q}$ denotes the number of covariates in category $q=\{z, x\}$ (see below). ${ }^{22}$ A prime denotes a transpose. To model unobserved heterogeneity at the country level, we include a $1 \times N$ row vector of dummies $\mathbf{d}_{n}^{\prime}$, which are equal to one in column $n$ and zero otherwise. Preferences of exporters differ by $\xi_{i j n t}$, which we take to have a known distribution. Finally, $\boldsymbol{\alpha}, \boldsymbol{\beta}$, and $\boldsymbol{\eta}$ are the coefficient vectors to be estimated.

Because traders are likely to choose currencies according to their attributes (e.g., the size of the exchange market or volatility of the exchange rate) and not only based on the (economic) characteristics of the currency's jurisdiction (e.g., a country's world trade share), we include both currency-specific and country-specific covariates in the estimating equation (Section 4.2). Specifying covariates as currency-specific allows us to identify the attributes of all currencies that could have been used in a trade transaction. For example, exchange rate volatility as a currency-specific variable can capture the volatility of the exporter's currency with respect to any currency choice. If exchange rate volatility were specified as a country-specific variable, it only identifies the exporter's currency and takes the same value for LCI (the Norwegian krone) and any vehicle currency. Not all variables are suitable to be specified as currency specific. Some variables (e.g., the exporter's world trade share) are better described as country specific. The euro effect is measured by using either a country-specific dummy or a currency-specific dummy.

Exporter $i$ in country $n$ chooses currency $j$ at time $t$ if and only if

$$
U_{i j n t} \geq U_{i k n t} \quad \forall k \neq j \text { and } k=1, \ldots, J
$$

Define the set of values of $\xi_{i j n t}$ that leads to the choice of currency $j$ in trade with country $n$ at time $t$ :

$$
A_{\text {jnt }}=\left\{\xi_{i j n t}: U_{i j n t} \geq U_{i k n t} \forall k \neq j, \quad k=1, \ldots, J\right\} .
$$

\footnotetext{
${ }^{22}$ We use $\mathbf{z}_{j n t}^{\prime}$ instead of $\mathbf{z}_{j t}^{\prime}$ to allow one of the currency-specific variables to vary by country.
} 
Let $\boldsymbol{\theta} \equiv\left[\begin{array}{lll}\boldsymbol{\alpha} & \boldsymbol{\beta} & \boldsymbol{\eta}\end{array}\right]^{\prime}$ be a row vector containing all the parameters. The currency share $j$ of country $n$ at time $t$ is a function of both currency and country characteristics:

$$
\mathrm{S}_{j n t}\left(\mathbf{Z}_{n t}, \mathbf{x}_{n t} ; \boldsymbol{\theta}\right)=\int_{\xi_{i j n t} \in A_{j n t}} d F\left(\xi_{i j n t}\right)
$$

where $F\left(\xi_{i j n t}\right)$ is the cumulative distribution function of $\xi_{\text {ijnt }}$ and $\mathbf{Z}_{n t}$ is a $J \times H_{z}$ matrix describing all currency choices $J$ and their characteristics $\mathbf{z}_{j}$. If the $\xi_{i j n t}$ 's are distributed independent and identically across firms, currencies, countries, and time periods with a Type I extreme-value distribution, the integral in (6) can be explicitly solved to yield the currency share function:

$$
\mathrm{S}_{j n t}=\frac{\exp \left(\mathbf{z}_{j n t}^{\prime} \boldsymbol{\alpha}+\mathbf{x}_{n t}^{\prime} \boldsymbol{\beta}+\mathbf{d}_{n}^{\prime} \boldsymbol{\eta}\right)}{\sum_{j}^{J} \exp \left(\mathbf{z}_{j n t}^{\prime} \boldsymbol{\alpha}+\mathbf{x}_{n t}^{\prime} \boldsymbol{\beta}+\mathbf{d}_{n}^{\prime} \boldsymbol{\eta}\right)}, \quad j \neq k .
$$

A probability-based approach like (7) ensures that estimated currency shares for $J$ currencies satisfy the adding-up constraint [see (1)] and are bounded on the closed interval [0,1]. We cannot use the much simpler logistic transformation because the shares might lie at the extreme values of zero or one, making the transformation impossible. In addition, a logistic transformation would also normalize to zero the coefficient of the Norwegian krone as a currency-specific variable, which is the base alternative for country-specific variables in our model. Such a normalization implies a loss of information.

The country-specific coefficient vectors $\boldsymbol{\beta}$ and $\boldsymbol{\eta}$ are only identified if we normalize one currency choice to zero. We choose to set the parameters of the Norwegian krone (LCI) to zero, leaving a parameter set for $J-1$ currency shares. Accordingly, the parameters in the vectors $\boldsymbol{\beta}$ and $\boldsymbol{\eta}$ represent the difference between the respective currency choice $j$ and the Norwegian krone. Without further restrictions, this approach would involve estimating $\left(N+H_{x}\right) \times(J-1)$ parameters for country-specific variables only. A more practical solution is to split the country-specific parameter vectors into the aforementioned three currency groups. We define $\boldsymbol{\beta}_{v}$ and $\boldsymbol{\eta}_{v}$ for $v \in\{\mathrm{LCI}, \mathrm{PCI}, \mathrm{VCI}\}$ and set $\boldsymbol{\beta}_{L C I}=\boldsymbol{\eta}_{L C I}=0$. This procedure implies that the parameters in the vectors $\boldsymbol{\beta}_{V C I}$ and $\boldsymbol{\eta}_{V C I}$ are identical across all vehicle currencies. Similarly, $\boldsymbol{\eta}_{P C I}$ and $\boldsymbol{\beta}_{P C I}$ are common to the euro and the eurozone legacy currencies that are used as PCI. More important, by distinguishing $J-1$ currency shares on 
the left-hand side, we can meaningfully include currency-specific variables. ${ }^{23}$ Obviously, the parameter vector $\boldsymbol{\alpha}$ remains unaffected by the splitting procedure. Note that if equation (7) had been specified without $\mathbf{z}_{j n t}$, we could have used just the three currency groups as the dependent variable. We can now define the normalized share function for the PCI and VCI groups:

$$
\mathrm{S}_{j n t}=\frac{\exp \left(\mathbf{z}_{j n t}^{\prime} \boldsymbol{\alpha}+\mathbf{x}_{n t}^{\prime} \boldsymbol{\beta}_{v}+\mathbf{d}_{n}^{\prime} \boldsymbol{\eta}_{v}\right)}{\exp \left(\mathbf{z}_{L C I n t}^{\prime} \boldsymbol{\alpha}\right)+\sum_{j}^{J-1} \exp \left(\mathbf{z}_{j n t}^{\prime} \boldsymbol{\alpha}+\mathbf{x}_{n t}^{\prime} \boldsymbol{\beta}_{v}+\mathbf{d}_{n}^{\prime} \boldsymbol{\eta}_{v}\right)} \forall j \neq k \neq \text { LCI. }
$$

Our model is a variant of the standard multinomial logit approach, which we call the conditional compositional multinomial logit model. To arrive at the estimated coefficient vector, we maximize the log-likelihood: ${ }^{24}$

$$
\ln L\left(\boldsymbol{\theta} \mid \mathbf{Z}_{n t}, \mathbf{x}_{n t}\right)=\sum_{n=1}^{N} \sum_{t=1}^{T} \sum_{j=1}^{J} s_{j n t} \ln S_{j n t},
$$

where $\boldsymbol{\theta} \equiv\left[\begin{array}{lllll}\boldsymbol{\alpha} & \boldsymbol{\beta}_{P C I} & \boldsymbol{\beta}_{V C I} & \boldsymbol{\eta}_{P C I} & \boldsymbol{\eta}_{V C I}\end{array}\right]^{\prime}$ is a row vector with parameters and $s_{j n t}$ are the observed currency shares. The estimated currency share functions are then the predicted currency shares; that is, $\hat{\mathrm{S}}_{j n t}=\hat{s}_{j n t}$, where hats denote predicted values (Appendix A.1). We use robust standard errors instead of standard errors clustered at the partner country level, reflecting the relatively small $N .^{25}$

In the benchmark specification, we explicitly control for unobserved heterogeneity across countries. To this end, we run a country-specific fixed effects model. Because $T=44$ is larger than $N=29$, we do not have to deal with the well-known incidental parameter problem. We formally test whether we should employ a fixed effects model or a pooled specification. Using the likelihood ratio test under the null hypothesis that the pooled model and the fixed effects model are statistically the same, we find: $-2\left[\ln L\left(a_{v}\right)-\ln L\left(\mathbf{d}_{n}^{\prime} \boldsymbol{\eta}_{v}\right)\right]=241.97>39.8=\chi^{2}(56)$, where $a_{v}$ is a common intercept per currency group and we have $2 \times(N-1)=56$ restrictions. The test statistic indicates that the hypothesis of poolability across countries can be rejected. As a robustness check, we also consider a pooled model, where we replace $\mathbf{d}_{n}^{\prime} \boldsymbol{\eta}_{v}$ by $a_{v}$.

\footnotetext{
${ }^{23}$ For purposes of analyzing currency-specific variables, all potential currencies of OECD countries are included even though five currencies were never chosen at all.

${ }^{24}$ The Matlab program code is available from the authors upon request.

${ }^{25}$ We have only 29 clusters, which is of insufficient size to use cluster-robust standard errors. Cameron et al. (2008) argue that at least 50 clusters are needed for accurate inference.
} 


\subsection{Explanatory Variables}

The analysis includes dummies to capture the introduction of the euro in non-cash form and the transition period after introduction, a set of trade and trade-related variables, and monetary variables. Table A.1 provides a detailed overview of the data sources and Table A.2 presents descriptive statistics.

\subsubsection{Euro Dummies}

To measure any unobserved effects on invoicing related to euro introduction (i.e., trust in the stability of the common currency), we employ a euro dummy. Changes in euro invoicing due to changes in fundamental variables (e.g., more price stability) should be captured sufficiently by the respective regressors (Sections 4.2.2 4.2.3). As a currency-specific variable, the euro dummy (denoted by $E U R_{j t}$ ) takes on a value of unity for the legacy currencies of the eurozone countries and for the euro from January 1, 1999 onward and zero otherwise (where the legacy currencies are included up to December 31,2001$).{ }^{26}$ The euro as a currency-specific variable measures the overall effect of euro introduction on the euro share in Norwegian imports including its use as a producer currency and vehicle currency. The parameter of $E U R_{j t}$ is expected to have a positive sign, since partner countries will take advantage of the increased market power bestowed upon them by the euro and trade less in any other currency than their own. As a country-specific variable, the euro dummy (denoted by $E U R_{n t}$ ) takes on a value of unity for all eurozone countries from January 1, 1999 onward. The country-specific euro dummy measures the effect of eurozone membership on a partner country's LCI, PCI, and VCI share. We expect a negative sign of the parameter of $E U R_{n t}$ for LCI and VCI and a positive sign for PCI.

From January 1, 1999 to December 31, 2001, the euro has been used in non-cash trade transactions alongside the national currencies of the eurozone countries. To measure the phasing out of the eurozone home currencies during the transition period, we use a dummy variable Euro Control Eut $_{t}$ that takes on a value of unity if one of the legacy currencies is chosen

\footnotetext{
${ }^{26}$ Note that the official date at which the national currencies of countries participating in the eurozone ceased to be legal tender varied across member states, but lasted up to a maximum of two months after December 31, 2001. However, we do not differentiate the date by country.
} 
during the transition period and zero otherwise. Based on the descriptive analysis in Section 3.2. we know that the euro slowly replaced the eurozone legacy currencies. Hence, we expect a negative coefficient of the Euro Control $_{j t}$ dummy.

\subsubsection{Monetary Variables}

Magee and Rao (1980) hypothesize that trading firms are less likely to set their prices in currencies of countries that exhibit a high rate of inflation. A high inflation rate weakens a country's currency and erodes the real value of the firm's trade receipts. We include the expected rate of inflation of the partner country $\left(C P I_{n t}\right)$, which is calculated as the mean of the consumer price index (CPI)-based inflation rate of the last four quarters. It is expected to have a negative effect on PCI by partner countries.

Cornell (1980) and Devereux et al. (2004) argue that the expected volatility of the partner country's inflation rate $C P I V_{\text {Vol }}$ nt will similarly have a negative effect on the use of the producer currency, because risk-averse exporters will want to minimize the variance of their receipts. Indeed, there are no appropriate instruments to hedge inflation uncertainty. We define CPIVol $n t$ as the standard deviation of a country's CPI over the last four quarters. As a currency-specific variable, $C P I V_{\text {Vol }} j$ is defined as the inflation volatility of the country or country group using currency $j$. We expect $C P I V o l_{j t}$ to be negative across currency groups.

According to Swoboda (1968), traders prefer a currency that has a thick foreign exchange market. Because of the smallness of a risk-averse trader relative to the market (atomicity), the risk of capital loss in a thick market is smaller than in a thin market. ${ }^{27}$ We expect the size of the foreign exchange market of currency $j$ (denoted by SizeF $X_{j t}$ ) to have a positive effect on currency share $j$. Ligthart and Da Silva (2007) and Goldberg and Tille (2008) measure the thickness of the foreign exchange market using the bid-ask spread of currency pairs. However, we use the fractions of the Bank of International Settlement's triennial survey on foreign exchange market activity. SizeFX ${ }_{j t}$ is calculated as a three-year moving average of the reported fractions. As a country-specific variable, SizeF $X_{n t}$ denotes the size of the foreign exchange market of country $n$ 's currency. We expect SizeFX $X_{n t}$ to have a positive effect on

\footnotetext{
${ }^{27}$ Krugman (1980) and Magee and Rao (1980) elaborate formally on the role of the lower transaction costs in deep, resilient markets.
} 
PCI and negative effect on VCI. Intuitively, a large foreign exchange market of the exporter's currency increases the use of his currency and reduces the need of a vehicle currency.

Baron (1976) was the first to argue that exporters will prefer to invoice in the currency whose relative price has the least volatility with a view to avoid revenue risk. Of course, firms could use forward contracts and currency options to hedge currency risk, but these are rather expensive methods for small firms and are typically not available for long time spans. ${ }^{28}$ The expected exchange rate volatility between the chosen currency $j$ and the Norwegian krone $\left(X\right.$ VoltoNOK $\left._{j t}\right)$ is calculated as the coefficient of variation of the nominal exchange rate during the last four quarters. $X$ VoltoNOK $_{j t}$ is expected to decrease the share of the chosen currency, irrespective of the currency group. As a country-specific variable, XVoltoNOK $K_{n t}$ is the expected exchange rate volatility between country n's currency and the Norwegian krone. XVoltoNOK $n$ is expected to be negative for the LCI and PCI shares and positive for the VCI share. Intuitively, traders will shift away from LCI and PCI to a third currency with lower volatility relative to the Norwegian krone or their home currency. Similarly, we include X VoltoPart $_{j n t}$, which represents the expected exchange rate volatility between the chosen currency $j$ and the producer's currency. This measure is also based on a four-quarter moving average of the coefficient of variation of the exchange rate. X VoltoPart $_{j n t}$ is expected to decrease the share of the chosen currency, again regardless of the currency type. ${ }^{29}$

\subsubsection{Trade Variables}

A country's market share is a key determinant of invoicing currency choice (cf. Swoboda, 1968; Bacchetta and Van Wincoop, 2005; Ligthart and Da Silva, 2007). Bacchetta and Van Wincoop (2005) argue that a larger world trade share increases a country's market power and thus its ability to impose its currency upon the trading partner. WorldTrade $_{n t}$ denotes a country's world trade share, which is calculated as the sum of the value of goods exports and imports of country $n$ divided by the sum of the value of world exports and imports of

\footnotetext{
${ }^{28}$ Borsum and Odegaard (2005) survey Norwegian firms about their currency hedging practices and find that small firms use more primitive hedging methods such as invoicing in the home currency, whereas large firms use forward contracts and currency options.

${ }^{29}$ By construction $X$ VoltoNOK $l$ for $l=\{n, j\}$ and $X$ VoltoPart $_{j n t}$ are zero for LCI and PCI, respectively. $X$ VoltoPart $_{j n t}$ is also the only variable that varies across currencies and countries.
} 
goods. The effect of WorldTrade W $_{\text {t }}$ is expected to be positive for PCI relative to invoicing in the Norwegian krone (LCI). Because the need to use an international currency is reduced, the effect on VCI should be negative.

McKinnon (1979) finds that homogeneous products that are traded on organized exchanges (e.g., oil) are often priced and invoiced in leading vehicle currencies like the US dollar. In addition, firms supplying differentiated goods under monopolistic competition have market power to set their prices freely and invoice in their own currency. However, Krugman (1987) and Betts and Devereux (2000) point out that firms producing differentiated final goods have an incentive to 'price to market.' As a result, the share of differentiated products of partner country $n$, which we label Diff $n t$, is expected to have a negative effect on VCI and an ambiguous effect on LCI and PCI. Diff $n t$ is calculated as the sum of imported goods that are classified to be differentiated by the conservative specification of the Rauch index (Rauch, 1999, p. 15) divided by the total value of Norwegian imports in that period. Rauch (1999) classifies commodities into three categories: traded on an organized exchange, reference priced, and differentiated at the three-digit and four-digit level of the Standard International Trade Classification (SITC). The conservative Rauch index minimizes the number of threedigit and four-digit commodities that are classified as either traded on an organized exchange or reference priced, whereas the liberal Rauch index maximizes those numbers.

To control for the composition of trade across countries, the partner country's share in total Norwegian trade NorwayTrade ${ }_{n t}$ is included. In view of the gravity model (cf. Anderson, 1979), this variable captures the net effect on bilateral trade flows of distance (negative effect) and a country's GDP (positive effect). NorwayTrade ${ }_{n t}$ is not likely to affect the preferences for either country's currency and, therefore, has an ambiguous effect on the trading partners' own currency shares (i.e., PCI and LCI). However, the effect on VCI is expected to be negative. Indeed, if goods markets of two economies are becoming more integrated there will be less need for a third currency. NorwayTrade $n t$ is defined as the sum of country $n$ 's value of goods exports to and goods imports from Norway divided by the sum of Norway's goods exports and imports. 


\section{Results}

This section presents the econometric results. We start off with the benchmark model and subsequently present alternative specifications. Besides serving as robustness checks, the alternative specifications help us in positioning our results within the invoicing literature.

\subsection{Currency-Specific and Country-Specific Variables}

\subsubsection{Benchmark Specification}

Table 4 reports results for the fixed effects benchmark model (labeled specification I), which includes all variables of Section 4.2 . The left panel of the table presents the average marginal effects of country-specific variables for the currency groups LCI, PCI, and VCI. Reported magnitudes represent the percentage point increase of currency share $v$ with respect to a one unit increase of the respective covariate. Variables showing significant marginal effects are inflation volatility $\left(C P I V o l_{n t}\right)$ for all three currency groups and the degree of differentiated products $\left(\right.$ Diff $\left._{n t}\right)$ for LCI and VCI. The magnitudes of the inflation rate $\left(C P I_{n t}\right)$ across currency groups are small and statistically insignificant for PCI and VCI. All three marginal effects of the CPIVol $n$ variable have their expected sign. An increase of one standard deviation in the inflation volatility of the exporter's economy reduces the share of PCI by 10.7 percentage points and increases the use of the local currency and vehicle currencies by 6.8 and 3.9 percentage points, respectively. Note that the logit specification of the currency share function ensures that the sum of the marginal effects always equals zero.

The effects for Diff $n t$ are much smaller: A 10 percentage points increase in the share of differentiated products decreases the use of vehicle currencies by 5 percentage points and increases the use of the Norwegian krone by 5 percentage points. Hence, we find support for Krugman's (1987) pricing-to-market theory. This result may be due to the ecological inference problem (cf. King, 1997), which may occur in studies using aggregate data. Given that we do not have micro data, the large transaction sizes of large exporting firms - which are more likely to commit to large local outposts and hence are more likely to price to marketoutweigh the small transaction sizes of small firms. Our qualitative finding on the LCI effect 
of differentiated goods is in line with that found by Ligthart and Da Silva (2007) — who use a more basic raw materials indicator - and Ito et al. (2010). However, we are the first to find a significant inflation volatility effect.

The right panel of Table 4 presents the average marginal effects of the currency-specific variables. Figures on the diagonal of each matrix represent the own effect and figures off the diagonal denote cross effects (i.e., with respect to the other currency groups). We find significant marginal effects for $E U R_{j t}$ and EuroControl ${ }_{j t}$. If the chosen currency is the euro, then its share increases by 2.6 percentage points when used as a producer currency (see the middle cell on the diagonal for the $E U R_{j t}$ dummy), whereas if it is chosen as a vehicle currency its share increases by almost 3 percentage points (see the bottom cell on the diagonal). ${ }^{30}$ Interestingly, as a counterfactual exercise, if the Norwegian krone were part of the eurozone, its share would have increased by 3.6 percentage points (see the first cell on the diagonal). The coefficient of EuroControl $j t$ indicates the speed of transition from the respective national legacy currency to the euro (or to any other currency). If the exporter's currency is a currency of the eurozone, then it reduces its invoicing share of the national legacy currency in any quarter between 1999 and 2001 by 2.1 percentage points and its invoicing share of vehicle currencies by 2.4 percentage points.

McFadden's pseudo $R^{2}$ of the fixed effects model is almost 0.4 , which is rather high for this type of nonlinear model and is much larger than in the model with country-specific covariates only (see Section 5.2). With the exception of the time of euro introduction and the transition period after introduction, the invoicing pattern is rather stable across time periods. However, in view of the rather large change in invoicing practices after euro introduction, we ran a structural break test with unknown change point as in Andrews (1993). We did not find evidence of a structural break, suggesting that our covariates account well enough for the change. ${ }^{31}$

\footnotetext{
${ }^{30}$ In Section 5.2 we discuss the specification with country-specific variables only, which is the one commonly used in the invoicing literature. In that section, we will further relate our findings with those of the literature.

${ }^{31}$ Results of the structural break test can be found in Figure A.1 of Ligthart and Werner (2011).
} 


\subsubsection{Alternative Specifications}

Table 5 considers a pooled model that estimates a common intercept across countries (which we label specification II). The model includes all variables of the benchmark model. Compared to the fixed effects model, we can see that the set of significant marginal effects expands. Within the set of country-specific marginal effects, we find that invoicing shares are affected by $C P I_{n t}$ and CPIVol $_{n t}$ for LCI, PCI, and VCI, Diff $n t$ for LCI and PCI, and NorwayTrade $n t$ for PCI and VCI. The marginal effect of $C P I V o l_{n t}$ for PCI is doubled compared to the fixed effects specification. Rather large is the inflation volatility effect, which also doubles. The marginal effect of $C P I_{n t}$ has the same sign but it is much smaller than that of $C P I V o l_{n t}$. As expected, NorwayTrade ${ }_{n t}$ decreases the share of vehicle currency invoicing in Norwegian imports. The marginal effects of the currency-specific variables $E U R_{j t}$, EuroControl ${ }_{j t}$, and SizeFX $X_{j t}$ are significant. The magnitudes for $E U R_{j t}$ increase from 2.6 percentage points in the benchmark case to 5.8 percentage points for PCI and from 3 percentage points to 6 percentage points for VCI. A 10 percentage points rise of a currency's foreign exchange market share increases its PCI and VCI share by 2 percentage points, which is a rather small magnitude.

One could argue that exporting firms located in a country whose currency has a deep and resilient foreign exchange market prefer their own currency and choose less often a vehicle currency; that is, $\operatorname{SizeF} X_{n t}$ is a country-specific variable rather than a currency-specific variable. We could also test whether traders choose a currency that has the least inflation volatility. Specifying inflation volatility as a currency-specific variable $\left(C P I V o l_{j t}\right)$ captures inflation volatility of the producer's currency relative to any other country's inflation volatility including Norway's. ${ }^{32}$ Specification III in Table 6 considers a fixed effects model in which we include CPIVol ${ }_{j t}$ and SizeFX $X_{n t}$ instead of CPIVol $n t$ and SizeFX $X_{j t}$. Significant countryspecific marginal effects are SizeFX $X_{n t}$ for LCI, PCI and VCI, CPI $I_{n t}$ for LCI and PCI, and Diff $_{n t}$ for LCI and VCI. A 10 percentage point increase in the size of the partner currency's foreign exchange market leads to an increase of 6 percentage points of the producer currency's

\footnotetext{
${ }^{32}$ Devereux et al. (2004) argue that a country's inflation volatility only matters with respect to its trading partner's inflation volatility.
} 
share, a fall of almost 2 percentage points of the local currency share, and a decrease of around 4 percentage points of vehicle currencies. In addition, we see that the marginal effects of the

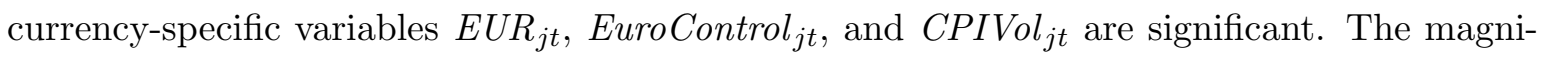
tude of $C P I V o l j t$ as a currency-specific variable is much lower than that as a country-specific variable. An increase of Norway's inflation volatility by one standard deviation reduces the invoicing share of the Norwegian krone by less than one percentage point. The same increase of inflation volatility of the exporter's currency depresses the invoicing share of the exporting firm by less than half of a percentage point.

\subsection{Country-Specific Variables}

Specification IV in Table 7 presents results for the pooled model, in which we assume that all explanatory variables are country specific. This specification is the standard model that has been previously used in the invoicing literature, either in a nonlinear model with three currency choices (cf. Wilander, 2006) or in a linear specification with one currency share (Kamps, 2006; Goldberg and Tille, 2008). Failing to control for unobserved heterogeneity, as is typical for invoicing studies, gives a greater number of significant marginal effects of the variables. We find six significant variables in the respective LCI and PCI groups and seven in the VCI group. The marginal effects of inflation and inflation volatility have similar magnitudes and signs as in specifications I and II. In addition to these variables and the euro dummy (in the case of PCI and VCI), we find WorldTrade Wt $_{\text {and }}$ VoltoNOK $_{n t}$ for LCI and VCI to be significant. A one percentage point increase of WorldTrade $_{n t}$ increases PCI by 8 percentage points, whereas LCI decreases by almost 13 percentage points. This result supports the findings of Ligthart and Da Silva (2007) and Goldberg and Tille (2008). In line with expectations, $X$ VoltoNOK $_{n t}$ reduces LCI and PCI and increases vehicle currency use. This finding is in line with the qualitative results of Wilander (2006), who does not provide average marginal effects. Compared to the benchmark specification, the pseudo $R^{2}$ of 0.15 of our alternative model is rather low.

The magnitude of the average marginal effect of the euro dummy is much larger than that in the benchmark model (where it enters as a currency-specific variable): A country's 
membership of the eurozone increases PCI by 19 percentage points. Intuitively, there is much more cross-sectional variation in the country-specific $E U R_{n t}$ dummy than in the currencyspecific $E U R_{j t}$ dummy. In addition, the presence of unobserved country-specific fixed effects that are correlated with the euro dummy may overstate the euro effect. The unobserved euro effect reduces VCI by almost 20 percentage points, suggesting that eurozone countries have been substituting away from vehicle currency use. However, this is only part of the story given that the drop in inflation volatility boosted the PCI shares of eurozone countries.

Specification V in Table 7 also considers country-specific variables only, but focuses on the fixed effects model. We find roughly the same set of significant variables as in specification III. Compared to the pooled model, the magnitudes of the marginal effects are greatly reduced. A country's membership of the eurozone now increases PCI by only 10.7 percentage points, suggesting that time-invariant country-specific factors contribute substantially to explaining the size of the PCI share. Kamps (2006) finds a marginal euro effect on PCI of 4.75 percent, which is much smaller. ${ }^{33}$ Finally, the pseudo $R^{2}$ of 0.22 is larger than its pooled counterpart, but still considerably lower than the benchmark specification.

\section{Conclusions}

Has the euro affected the choice of invoicing currency? At first sight, the answer to this question seems an obvious 'yes' given that the euro did not exist prior to 1999. However, we are interested in measuring whether the euro has had an effect on the home currency share of eurozone exporters (so-called producer currency invoicing) above and beyond their home currency share prior to euro introduction. In addition, we measure the euro's effect on the share of the importer's home currency and the shares of respective vehicle currencies. To this end, we use quarterly data on the currency composition of Norwegian goods imports from OECD countries covering the period 1996-2006.

The descriptive analysis shows that the introduction of the euro increases the producer currency share of eurozone exporters at the expense of the Norwegian krone and vehicle

\footnotetext{
${ }^{33}$ However, it rather difficult to directly compare our findings with this study because she estimates the currency shares without any lower and upper bound and does not control for the interaction with other shares.
} 
currencies. In contrast, non-eurozone exporters experience a slight fall in their producer currency share. However, the rise in the producer currency share of eurozone countries can only be partly attributed to a substitution from eurozone vehicle currencies to the euro. We also find that the euro has replaced the US dollar as the dominant currency in the group of vehicle currencies.

In the econometric analysis, we distinguish 31 currencies and calculate the corresponding bilateral currency shares rather than focusing on a single currency share. This approach allows to capture substitution effects between currencies owing to euro introduction. Currency shares are explained by currency-specific variables as well as by country-specific variables while controlling for unobserved country heterogeneity. The results for the fixed effects benchmark model reveal that the substantial rise in the share of producer currency invoicing by eurozone countries is primarily caused by a drop in inflation volatility and can only to a small extent be explained by an unobserved euro effect. The introduction of the euro increases the share of producer currency invoicing by eurozone countries by only 2.6 percentage points. If the euro is chosen as a vehicle currency by non-eurozone countries its share rises by 3 percentage points. This unobserved euro effect only materialized gradually, reflecting the three-year transition phase and hysteresis in invoicing practices.

The larger euro invoicing share in Norwegian imports has increased ceteris paribus Norway's trade account exposure to exchange rate changes. A depreciation of the Norwegian krone leads to a larger trade deficit and more 'imported inflation' than before the introduction of the euro. Countries like Greece, Italy, Portugal, and Spain (GIPS) have enjoyed the largest increases in their own currency share (i.e., the euro). In view of the recent eurozone crisis, various observers have speculated about a likely exit of the GIPS countries from the eurozone. In case of a eurozone breakup scenario, all trade payments of a country exiting the eurozone may overnight be converted from euros into a new local currency at a fixed conversion rate. Such conversion could favorably affect profits of Norwegian importers, who used to be invoiced in euros and will now be paid in the new local currency, as the new currency may depreciate rapidly versus the euro and Norwegian krone.

We should note that all our results are derived based on data for a single country (Norway). 
However, the bilateral nature of the invoicing data allows us to capture both the observed and unobserved characteristics of Norway's trading partners. Of course, invoicing data for a single country could be affected more by idiosyncracies than in a pure cross-country analysis. Future research could therefore usefully focus on checking the robustness of our findings by analyzing invoicing data for other countries than Norway and by studying time periods succeeding our sample. Second, one could analyze invoicing transactions at the firm level, potentially via a survey of eurozone firms. Such a micro-based approach has the advantage that information on firm size and transaction volumes can be used in the analysis. This approach also allows the use of pure discrete choice models with random taste variation. 
Figure 1: Currency Group Shares in Norwegian Imports

(a) Eurozone countries (equally weighted)

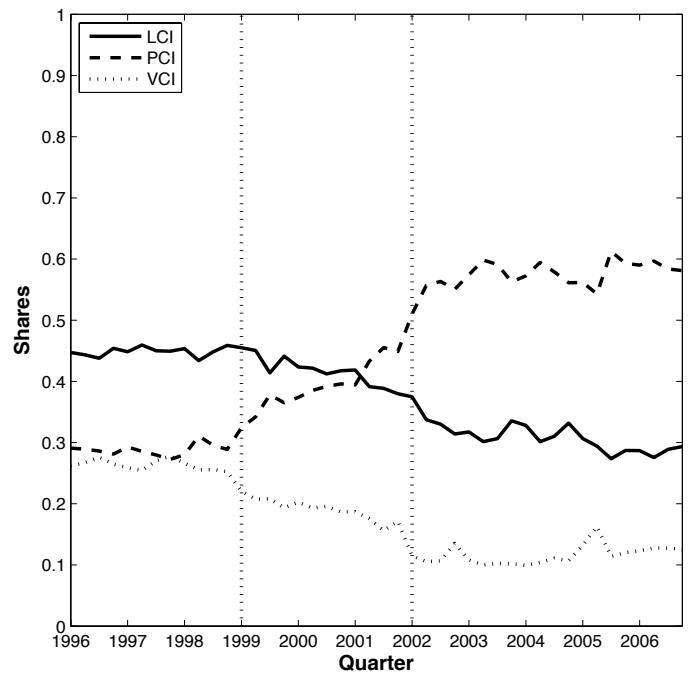

(c) Euro and non-euro (equally weighted)

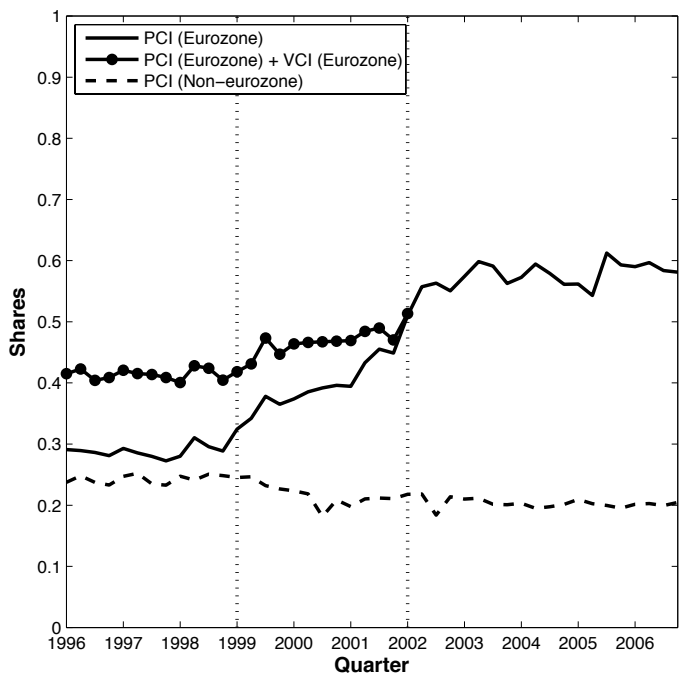

(b) Eurozone countries (trade weighted)

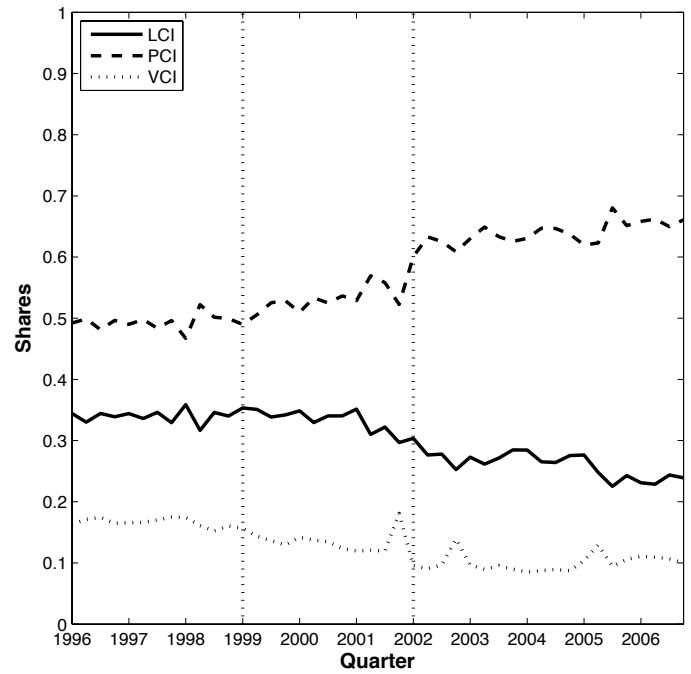

(d) Euro and non-euro (trade weighted)

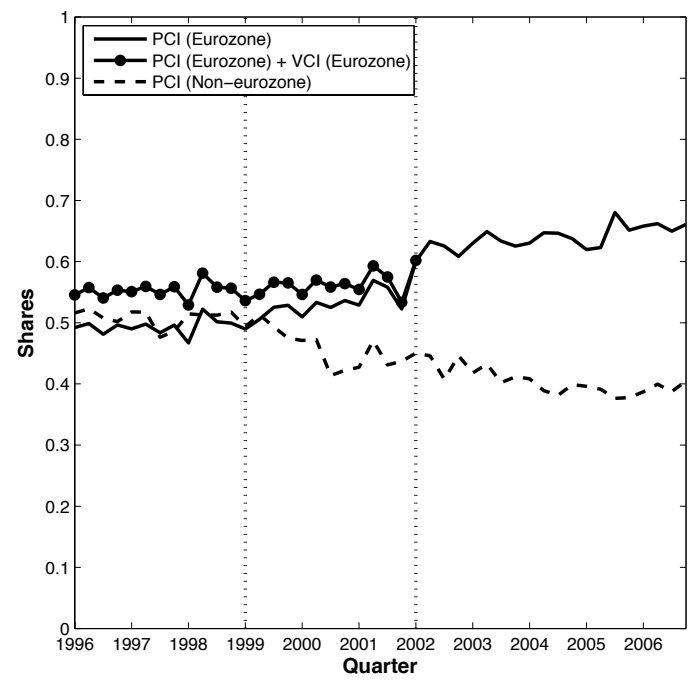

Notes: The data in Panels (a) and (b) pertain to all countries in the eurozone. The thick solid line represents the share of local currency invoicing (LCI, i.e., the Norwegian krone), the dashed line denotes the share of producer currency invoicing (PCI), and the dotted line depicts the share of vehicle currency invoicing (VCI). The data in Panels (c) and (d) cover all OECD countries excluding Norway, where a distinction is made between eurozone and non-eurozone countries. The thick solid line represents the PCI share of countries in the eurozone and the dashed line denotes the PCI share of non-eurozone countries. The bullet pointed line denotes the sum of the eurozone PCI and VCI shares. The first vertical line indicates the introduction of the euro in non-cash form and the second vertical line represents the introduction of the euro in cash transactions. 
Figure 2: Vehicle Currency Shares in Norwegian Imports

(a) Non-eurozone countries excluding the US (equally weighted)

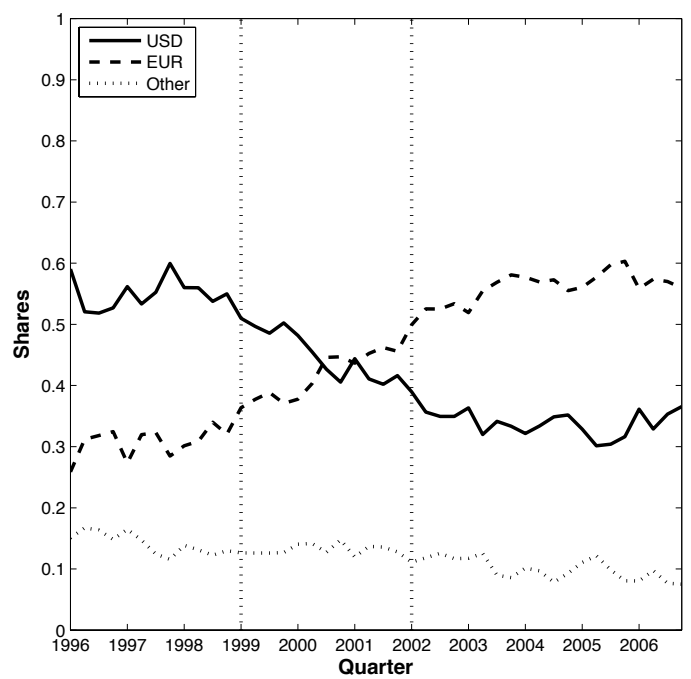

(b) Non-eurozone countries excluding the US (trade weighted)

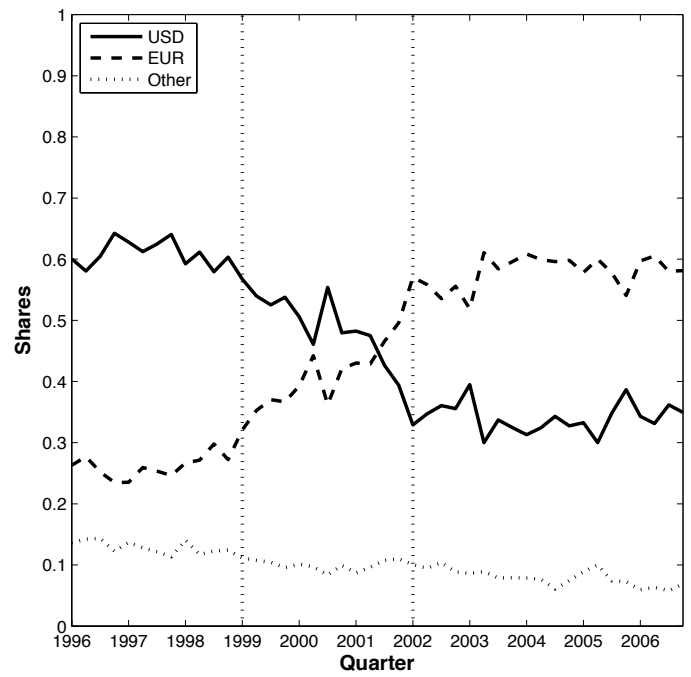

Notes: The data in Panels (a) and (b) pertain to all OECD countries, except the United States and eurozone countries. The thick solid line represents the share of vehicle currency invoicing in US dollar (USD), the dashed line denotes the share of vehicle currency invoicing in the eurozone legacy currencies and in the euro (EUR), and the dotted line depicts the share of vehicle currency invoicing in other currencies (Other). The first vertical line indicates the introduction of the euro in non-cash form and the second vertical line represents the introduction of the euro in cash transactions. 


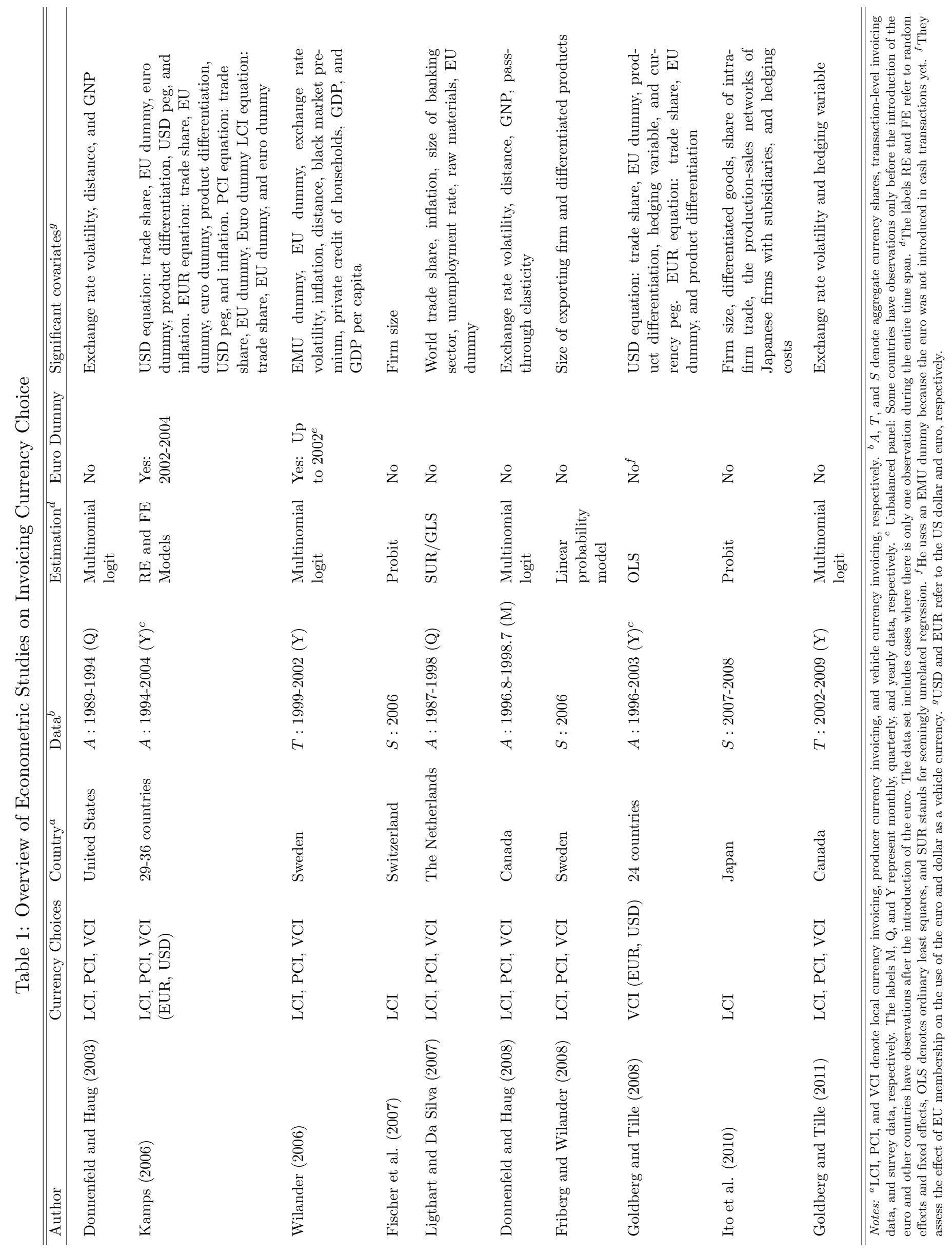


Table 2: Currency Group Shares by OECD Country, Averages for 1996-2006 (in Percent)

\begin{tabular}{|c|c|c|c|c|}
\hline \multirow[t]{2}{*}{ Country } & \multirow{2}{*}{$\begin{array}{r}\text { Import } \\
\text { Share }\end{array}$} & \multicolumn{3}{|c|}{ Currency Shares } \\
\hline & & LCI & PCI & VCI \\
\hline Sweden & 15.619 & 43.239 & 45.880 & 10.881 \\
\hline Germany* & 13.842 & 19.677 & 73.516 & 6.807 \\
\hline United Kingdom & 8.074 & 27.694 & 43.359 & 28.947 \\
\hline Denmark & 7.367 & 37.217 & 45.492 & 17.291 \\
\hline United States & 6.400 & 16.121 & 71.487 & 12.392 \\
\hline Netherlands* & 4.522 & 27.144 & 53.956 & 18.900 \\
\hline France* & 4.479 & 31.630 & 55.079 & 13.291 \\
\hline Italy* & 3.771 & 31.586 & 55.709 & 12.705 \\
\hline Finland* & 3.480 & 61.422 & 33.262 & 5.316 \\
\hline Japan & 3.415 & 38.116 & 21.798 & 40.085 \\
\hline Canada & 2.378 & 4.378 & 75.311 & 20.311 \\
\hline Belgium* & 2.290 & 36.963 & 42.542 & 20.495 \\
\hline Spain* & 1.618 & 34.442 & 49.668 & 15.891 \\
\hline Ireland* & 1.457 & 33.957 & 16.198 & 49.845 \\
\hline Poland & 1.234 & 38.228 & 1.673 & 60.099 \\
\hline Switzerland & 1.229 & 25.808 & 45.922 & 28.271 \\
\hline Austria* & 0.912 & 28.854 & 60.444 & 10.702 \\
\hline Korea & 0.713 & 24.273 & 0 & 75.727 \\
\hline Czech Republic & 0.580 & 57.197 & 0.880 & 41.923 \\
\hline Portugal* ${ }^{*}$ & 0.575 & 55.399 & 30.513 & 14.089 \\
\hline Turkey & 0.517 & 37.776 & 0 & 62.224 \\
\hline Hungary & 0.408 & 49.612 & 0 & 50.388 \\
\hline Iceland & 0.249 & 56.708 & 1.707 & 41.585 \\
\hline Australia & 0.216 & 9.470 & 9.244 & 81.286 \\
\hline Mexico & 0.129 & 29.698 & 0 & 70.302 \\
\hline Greece* & 0.127 & 42.195 & 34.570 & 23.235 \\
\hline Slovak Republic & 0.117 & 44.067 & 0 & 55.933 \\
\hline Luxembourg* & 0.075 & 49.308 & 29.625 & 21.066 \\
\hline New Zealand & 0.043 & 35.562 & 7.911 & 56.528 \\
\hline Average (equally weighted) & 2.960 & 35.439 & 31.233 & 33.328 \\
\hline
\end{tabular}

Notes: The countries are ranked by their share in Norwegian imports. To conserve on space, columns (2)-(4) report the currency shares for three aggregate currency groups using equation (2): LCI, PCI, and VCI refer to the invoicing share of the local currency (Norwegian krone), currencies of partner countries (i.e., the producer currencies), and vehicle currencies, respectively. An asterisk indicates that the country is a member of the eurozone on January 1, 2002. All currency fractions are averaged across 1996-2006 and expressed in percentages. 
Table 3: Vehicle Currency Shares, 1996 and 2006 (in Percent)

\begin{tabular}{|c|c|c|c|}
\hline Year & Currencies & $\begin{array}{r}\text { Share of All } \\
\text { Currencies }\end{array}$ & $\begin{array}{l}\text { Share of All } \\
\text { Vehicle Currencies }\end{array}$ \\
\hline \multirow[t]{23}{*}{1996} & Total & 37.4666 & 100.0000 \\
\hline & US dollar & 19.7697 & 52.7662 \\
\hline & Eurozone & 12.0287 & 32.1052 \\
\hline & German mark & 10.1230 & 27.0186 \\
\hline & Dutch guilder & 0.6693 & 1.7864 \\
\hline & Belgian franc & 0.4894 & 1.3062 \\
\hline & ECU & 0.3444 & 0.9192 \\
\hline & Austrian schilling & 0.1645 & 0.4392 \\
\hline & French franc & 0.1381 & 0.3685 \\
\hline & Finnish mark & 0.0529 & 0.1411 \\
\hline & Italian lira & 0.0258 & 0.0689 \\
\hline & Irish pound & 0.0113 & 0.0302 \\
\hline & Spanish peseta & 0.0072 & 0.0193 \\
\hline & Portuguese escudo & 0.0028 & 0.0075 \\
\hline & Non-eurozone & 5.6682 & 15.1286 \\
\hline & Swedish krona & 3.4730 & 9.2697 \\
\hline & Danish krone & 1.1570 & 3.0881 \\
\hline & Pound sterling & 0.7503 & 2.0026 \\
\hline & Swiss franc & 0.2421 & 0.6463 \\
\hline & Japanese yen & 0.0389 & 0.1037 \\
\hline & Canadian dollar & 0.0060 & 0.0160 \\
\hline & Australian dollar & 0.0007 & 0.0018 \\
\hline & Iceland krona & 0.0001 & 0.0003 \\
\hline \multirow[t]{14}{*}{2006} & Total & 30.9928 & 100.0000 \\
\hline & Euro & 14.6061 & 47.1274 \\
\hline & US dollar & 12.8751 & 41.5424 \\
\hline & Swedish krona & 2.1265 & 6.8612 \\
\hline & Danish krone & 0.9188 & 2.9644 \\
\hline & Pound sterling & 0.3650 & 1.1777 \\
\hline & Swiss franc & 0.0533 & 0.1721 \\
\hline & Japanese yen & 0.0237 & 0.0763 \\
\hline & Canadian dollar & 0.0175 & 0.0566 \\
\hline & Czech koruna & 0.0027 & 0.0087 \\
\hline & Polish zloty & 0.0025 & 0.0080 \\
\hline & Australian dollar & 0.0015 & 0.0047 \\
\hline & New Zealand dollar & 0.0001 & 0.0003 \\
\hline & Iceland krona & 0.0000 & 0.0001 \\
\hline
\end{tabular}

Notes: The first column with data presents the average trade-weighted currency shares with respect to all currencies, whereas the second column shows the currency shares with respect to all vehicle currencies. All currency fractions are expressed in percentages. 
Table 4: Average Marginal Effects for the Benchmark Model (Specification I)

\begin{tabular}{|c|c|c|c|c|c|}
\hline Country Specific & & Currency Specific & & & \\
\hline \multirow[t]{2}{*}{ LCI } & & $E U R$ & & & \\
\hline & & & LCI & PCI & VCI \\
\hline \multirow[t]{2}{*}{$C P I$} & $0.0061^{*}$ & LCI & $0.0361^{* * *}$ & $-0.0164^{* * *}$ & $-0.0197^{*}$ \\
\hline & $(0.0032)$ & & $(0.0046)$ & $(0.0022)$ & $(0.0114)$ \\
\hline \multirow[t]{2}{*}{ CPIVol } & $0.0678^{* * *}$ & PCI & & $0.0263^{* * *}$ & $-0.0098 * * *$ \\
\hline & $(0.0127)$ & & & $(0.0035)$ & $(0.0029)$ \\
\hline \multirow[t]{2}{*}{ WorldTrade } & -0.0002 & VCI & & & $0.0296^{* * *}$ \\
\hline & $(0.0316)$ & & & & $(0.0050)$ \\
\hline \multirow[t]{2}{*}{ NorwayTrade } & -0.0002 & & & & \\
\hline & $(0.0089)$ & EuroControl ${ }^{\dagger}$ & & & \\
\hline \multirow[t]{3}{*}{ Diff } & $0.0051^{* *}$ & & LCI & PCI & VCI \\
\hline & $(0.0024)$ & LCI & $-0.0290^{* * *}$ & $0.0131^{* * *}$ & 0.0158 \\
\hline & & & $(0.0059)$ & $(0.0027)$ & $(0.0097)$ \\
\hline \multirow[t]{2}{*}{ PCI } & & PCI & & $-0.0211^{* * *}$ & $0.0079 * * *$ \\
\hline & & & & $(0.0044)$ & $(0.0027)$ \\
\hline \multirow[t]{2}{*}{$C P I$} & -0.0066 & VCI & & & $-0.0238 * * *$ \\
\hline & $(0.0048)$ & & & & $(0.0053)$ \\
\hline \multirow[t]{2}{*}{ CPIVol } & $-0.1068 * * *$ & & & & \\
\hline & $(0.0200)$ & SizeFX & & & \\
\hline \multirow[t]{2}{*}{ WorldTrade } & 0.0006 & & LCI & PCI & VCI \\
\hline & $(0.0270)$ & LCI & 0.0002 & -0.0001 & -0.0001 \\
\hline \multirow[t]{2}{*}{ NorwayTrade } & 0.0025 & & $(0.0002)$ & $(0.0001)$ & $(0.0002)$ \\
\hline & $(0.0090)$ & PCI & & 0.0001 & -0.0001 \\
\hline \multirow[t]{3}{*}{ Diff } & 0.0002 & & & $(0.0002)$ & $(0.0001)$ \\
\hline & $(0.0012)$ & VCI & & & 0.0002 \\
\hline & & & & & $(0.0002)$ \\
\hline \multicolumn{6}{|l|}{ VCI } \\
\hline & & $X$ VoltoNOK & & & \\
\hline \multirow[t]{2}{*}{$C P I$} & 0.0005 & & LCI & PCI & VCI \\
\hline & $(0.0020)$ & LCI & 0.1052 & -0.0476 & -0.0574 \\
\hline \multirow[t]{2}{*}{ CPIVol } & $0.0388 * * *$ & & $(0.0761)$ & $(0.0346)$ & $(0.0549)$ \\
\hline & $(0.0124)$ & PCI & & 0.0764 & -0.0287 \\
\hline \multirow[t]{2}{*}{ WorldTrade } & -0.0004 & & & $(0.0556)$ & $(0.0237)$ \\
\hline & $(0.0334)$ & VCI & & & 0.0862 \\
\hline \multirow[t]{2}{*}{ NorwayTrade } & -0.0023 & & & & $(0.0651)$ \\
\hline & $(0.0115)$ & & & & \\
\hline \multirow[t]{3}{*}{ Diff } & $-0.0053^{* * *}$ & XVoltoPart & & & \\
\hline & $(0.0014)$ & & LCI & PCI & VCI \\
\hline & & LCI & -0.1342 & 0.0608 & 0.0732 \\
\hline \multirow[t]{2}{*}{ Diagnostics } & & & $(0.0841)$ & $(0.0384)$ & $(0.0662)$ \\
\hline & & PCI & & -0.0975 & 0.0366 \\
\hline Observations & 1,276 & & & $(0.0617)$ & $(0.0269)$ \\
\hline Log-Likelihood & $-2,493.17$ & VCI & & & -0.1100 \\
\hline McFadden Pseudo $R^{2}$ & 0.39 & & & & $(0.0718)$ \\
\hline
\end{tabular}

Notes: The dependent variable denotes currency share $j$ of country $n$ at time $t$. The left-hand side gives the average marginal effects for the country-specific variables, whereas the right-hand side presents the average marginal effects for the currency-specific variables. The latter panel presents on the diagonal the elasticities with respect to the own currency group and reports off-diagonal the elasticities with respect to the other currency group (i.e., PCI, LCI, and $\mathrm{VCI}) . * * *, * *, *$ denote significance at the 1,5 or 10 percent level, respectively. Robust standard errors are reported in parentheses below the estimated average marginal effects. A † indicates that we have averaged the EuroControl dummy across all $n$ countries and $t=1999 Q 1, \ldots, 2001 Q 4$ (i.e., the transition period). 
Table 5: Average Marginal Effects for Specification II

\begin{tabular}{|c|c|c|c|c|c|}
\hline \multicolumn{2}{|l|}{ Country Specific } & \multicolumn{4}{|l|}{ Currency Specific } \\
\hline \multirow[t]{2}{*}{ LCI } & & $E U R$ & & & \\
\hline & & & LCI & PCI & VCI \\
\hline \multirow[t]{2}{*}{$C P I$} & $0.0211^{* * *}$ & LCI & $0.0737^{* * *}$ & $-0.0355 * * *$ & $-0.0375^{*}$ \\
\hline & $(0.0027)$ & & $(0.0051)$ & $(0.0027)$ & $(0.0213)$ \\
\hline \multirow[t]{2}{*}{ CPIVol } & $0.1225^{* * *}$ & PCI & & $0.0576^{* * *}$ & $-0.0218^{* *}$ \\
\hline & $(0.0181)$ & & & $(0.0042)$ & $(0.0100)$ \\
\hline \multirow[t]{2}{*}{ WorldTrade } & -0.0022 & VCI & & & $0.0600 * * *$ \\
\hline & $(0.0078)$ & & & & $(0.0145)$ \\
\hline \multirow[t]{2}{*}{ NorwayTrade } & -0.0021 & & & & \\
\hline & $(0.0046)$ & EuroControl ${ }^{\dagger}$ & & & \\
\hline \multirow[t]{3}{*}{ Diff } & $0.0019 * * *$ & & LCI & PCI & VCI \\
\hline & $(0.0005)$ & LCI & $-0.0444^{* * *}$ & $0.0214^{* * *}$ & $0.0226^{*}$ \\
\hline & & & $(0.0066)$ & $(0.0033)$ & $(0.0136)$ \\
\hline \multirow[t]{2}{*}{ PCI } & & PCI & & $-0.0347 * * *$ & $0.0131^{* *}$ \\
\hline & & & & $(0.0052)$ & $(0.0066)$ \\
\hline \multirow[t]{2}{*}{$C P I$} & $-0.0352^{* * *}$ & VCI & & & $-0.0361^{* * *}$ \\
\hline & $(0.0044)$ & & & & $(0.0105)$ \\
\hline \multirow[t]{2}{*}{ CPIVol } & $-0.2060 * * *$ & & & & \\
\hline & $(0.0289)$ & SizeFX & & & \\
\hline \multirow[t]{2}{*}{ WorldTrade } & 0.0057 & & LCI & PCI & VCI \\
\hline & $(0.0077)$ & LCI & $0.0025^{* * *}$ & $-0.0012^{* * *}$ & $-0.0013^{*}$ \\
\hline \multirow[t]{2}{*}{ NorwayTrade } & $0.0242^{* * *}$ & & $(0.0002)$ & $(0.0001)$ & $(0.0008)$ \\
\hline & $(0.0028)$ & PCI & & $0.0020^{* * *}$ & $-0.0007^{* *}$ \\
\hline \multirow[t]{3}{*}{ Diff } & $-0.0021^{* * *}$ & & & $(0.0001)$ & $(0.0004)$ \\
\hline & $(0.0005)$ & VCI & & & $0.0021^{* * *}$ \\
\hline & & & & & $(0.0005)$ \\
\hline \multicolumn{6}{|l|}{ VCI } \\
\hline & & $X$ VoltoNOK & & & \\
\hline \multirow[t]{2}{*}{$C P I$} & $0.0139^{* *}$ & & LCI & PCI & VCI \\
\hline & $(0.0060)$ & LCI & $-0.1760^{*}$ & $0.0847^{*}$ & 0.0896 \\
\hline \multirow[t]{2}{*}{ CPIVol } & $0.0823^{* *}$ & & $(0.1036)$ & $(0.0493)$ & $(0.0582)$ \\
\hline & $(0.0362)$ & PCI & & $-0.1377^{*}$ & $0.0521^{*}$ \\
\hline \multirow[t]{2}{*}{ WorldTrade } & -0.0035 & & & $(0.0804)$ & $(0.0306)$ \\
\hline & $(0.0055)$ & VCI & & & $-0.1432^{*}$ \\
\hline \multirow[t]{2}{*}{ NorwayTrade } & $-0.0221^{* * *}$ & & & & $(0.0785)$ \\
\hline & $(0.0060)$ & & & & \\
\hline \multirow[t]{3}{*}{ Diff } & 0.0002 & XVoltoPart & & & \\
\hline & $(0.0004)$ & & LCI & PCI & VCI \\
\hline & & LCI & 0.0340 & -0.0164 & -0.0173 \\
\hline \multirow[t]{2}{*}{ Diagnostics } & & & $(0.1017)$ & $(0.0488)$ & $(0.0488)$ \\
\hline & & PCI & & 0.0266 & -0.0101 \\
\hline Observations & 1,276 & & & $(0.0794)$ & $(0.0285)$ \\
\hline Log-Likelihood & $-2,614.15$ & VCI & & & 0.0277 \\
\hline McFadden Pseudo $R^{2}$ & 0.36 & & & & $(0.0804)$ \\
\hline
\end{tabular}

Notes: The dependent variable denotes currency share $j$ of country $n$ at time $t$. The left-hand side gives the average marginal effects for the country-specific variables, whereas the right-hand side presents the average marginal effects for the currency-specific variables. The latter panel presents on the diagonal the elasticities with respect to the own currency group and reports off-diagonal the elasticities with respect to the other currency group (i.e., PCI, LCI, and $\mathrm{VCI}) . * * *, * *, *$ denote significance at the 1,5 or 10 percent level, respectively. Robust standard errors are reported in parentheses below the estimated average marginal effects. A $\dagger$ indicates that we have averaged the EuroControl dummy across all $n$ countries and $t=1999 Q 1, \ldots, 2001 Q 4$ (i.e., the transition period). 
Table 6: Average Marginal Effects for Specification III

\begin{tabular}{|c|c|c|c|c|c|}
\hline \multicolumn{2}{|l|}{ Country Specific } & \multicolumn{4}{|l|}{ Currency Specific } \\
\hline \multirow[t]{2}{*}{ LCI } & & $E U R$ & & & \\
\hline & & & LCI & PCI & VCI \\
\hline \multirow[t]{2}{*}{$C P I$} & $0.0108^{* * *}$ & LCI & $0.0194^{* * *}$ & $-0.0087^{* * *}$ & $-0.0107^{*}$ \\
\hline & $(0.0028)$ & & $(0.0044)$ & $(0.0020)$ & $(0.0055)$ \\
\hline \multirow[t]{2}{*}{ SizeFX } & $-0.0019^{* *}$ & PCI & & $0.0139 * * *$ & $-0.0052^{* * *}$ \\
\hline & $(0.0009)$ & & & $(0.0032)$ & $(0.0017)$ \\
\hline \multirow[t]{2}{*}{ WorldTrade } & -0.0002 & VCI & & & $0.0159 * * *$ \\
\hline & $(0.0324)$ & & & & $(0.0040)$ \\
\hline \multirow[t]{2}{*}{ NorwayTrade } & -0.0001 & & & & \\
\hline & $(0.0089)$ & EuroControl ${ }^{\dagger}$ & & & \\
\hline \multirow[t]{3}{*}{ Diff } & $0.0054^{* * *}$ & & LCI & PCI & VCI \\
\hline & $(0.0020)$ & LCI & $-0.0382^{* * *}$ & $0.0171^{* * *}$ & $0.0211^{* * *}$ \\
\hline & & & $(0.0050)$ & $(0.0022)$ & $(0.0082)$ \\
\hline \multirow[t]{2}{*}{ PCI } & & PCI & & $-0.0274 * * *$ & $0.0102^{* * *}$ \\
\hline & & & & $(0.0036)$ & $(0.0023)$ \\
\hline \multirow[t]{2}{*}{$C P I$} & $-0.0137^{* * *}$ & VCI & & & $-0.0314^{* * *}$ \\
\hline & $(0.0043)$ & & & & $(0.0055)$ \\
\hline \multirow[t]{2}{*}{ SizeFX } & $0.0061^{* * *}$ & & & & \\
\hline & $(0.0007)$ & CPIVol & & & \\
\hline \multirow[t]{2}{*}{ WorldTrade } & 0.0005 & & LCI & PCI & VCI \\
\hline & $(0.0286)$ & LCI & $-0.0060^{* * *}$ & $0.0027 * * *$ & $0.0033^{* *}$ \\
\hline \multirow[t]{2}{*}{ NorwayTrade } & 0.0021 & & $(0.0012)$ & $(0.0006)$ & $(0.0016)$ \\
\hline & $(0.0089)$ & PCI & & $-0.0043^{* * *}$ & $0.0016^{* * *}$ \\
\hline \multirow[t]{2}{*}{ Diff } & -0.0004 & & & $(0.0009)$ & $(0.0005)$ \\
\hline & $(0.0011)$ & VCI & & & $\begin{array}{l}-0.0049^{* * *} \\
(0.0012)\end{array}$ \\
\hline \multicolumn{6}{|l|}{ VCI } \\
\hline & & $X$ VoltoNOK & & & \\
\hline \multirow[t]{2}{*}{$C P I$} & 0.0028 & & LCI & PCI & VCI \\
\hline & $(0.0020)$ & LCI & 0.1298 & -0.0581 & -0.0715 \\
\hline \multirow[t]{2}{*}{ SizeFX } & $-0.0042^{* * *}$ & & $(0.0839)$ & $(0.0378)$ & $(0.0612)$ \\
\hline & $(0.0009)$ & PCI & & 0.0930 & -0.0347 \\
\hline \multirow[t]{2}{*}{ WorldTrade } & -0.0003 & & & $(0.0607)$ & $(0.0264)$ \\
\hline & $(0.0336)$ & VCI & & & 0.1064 \\
\hline \multirow[t]{2}{*}{ NorwayTrade } & -0.0020 & & & & $(0.0719)$ \\
\hline & $(0.0118)$ & & & & \\
\hline \multirow[t]{3}{*}{ Diff } & $-0.0050 * * *$ & XVoltoPart & & & \\
\hline & $(0.0013)$ & & LCI & PCI & VCI \\
\hline & & LCI & -0.0348 & 0.0156 & 0.0191 \\
\hline \multirow[t]{2}{*}{ Diagnostics } & & & $(0.0862)$ & $(0.0387)$ & $(0.0498)$ \\
\hline & & PCI & & -0.0249 & 0.0093 \\
\hline Observations & 1,276 & & & $(0.0619)$ & $(0.0237)$ \\
\hline Log-Likelihood & $-2,252.63$ & VCI & & & -0.0285 \\
\hline McFadden Pseudo $R^{2}$ & 0.39 & & & & $(0.0712)$ \\
\hline
\end{tabular}

Notes: The dependent variable denotes currency share $j$ of country $n$ at time $t$. The left-hand side gives the average marginal effects for the country-specific variables, whereas the right-hand side presents the average marginal effects for the currency-specific variables. The latter panel presents on the diagonal the elasticities with respect to the own currency group and reports off-diagonal the elasticities with respect to the other currency group (i.e., PCI, LCI, and $\mathrm{VCI}) . * * *, * *, *$ denote significance at the 1,5 or 10 percent level, respectively. Robust standard errors are reported in parentheses below the estimated average marginal effects. A $\dagger$ indicates that we have averaged the EuroControl dummy across all $n$ countries and $t=1999 Q 1, \ldots, 2001 Q 4$ (i.e., the transition period). 
Table 7: Average Marginal Effects for Specifications IV and V

\begin{tabular}{|c|c|c|}
\hline & (IV) & $(\mathrm{V})$ \\
\hline \multicolumn{3}{|l|}{ LCI } \\
\hline \multirow[t]{2}{*}{$E U R$} & 0.0039 & 0.0153 \\
\hline & $(0.0310)$ & $(0.0280)$ \\
\hline \multirow[t]{2}{*}{$C P I$} & $0.0145^{* * *}$ & 0.0029 \\
\hline & $(0.0021)$ & $(0.0025)$ \\
\hline \multirow[t]{2}{*}{ CPIVol } & $0.0632^{* * *}$ & $0.0366^{* * *}$ \\
\hline & $(0.0141)$ & $(0.0095)$ \\
\hline \multirow[t]{2}{*}{ SizeFX } & 0.0017 & $-0.0033^{* *}$ \\
\hline & $(0.0018)$ & $(0.0016)$ \\
\hline \multirow[t]{2}{*}{ XVoltoNOK } & $-0.7791 * * *$ & -0.2333 \\
\hline & $(0.2788)$ & $(0.1476)$ \\
\hline \multirow[t]{2}{*}{ WorldTrade } & $-0.1275^{* * *}$ & -0.0022 \\
\hline & $(0.0103)$ & $(0.0192)$ \\
\hline \multirow[t]{2}{*}{ NorwayTrade } & $0.0110^{* * *}$ & -0.0033 \\
\hline & $(0.0011)$ & $(0.0074)$ \\
\hline \multirow[t]{2}{*}{ Diff } & $0.0009 * * *$ & 0.0006 \\
\hline & $(0.0002)$ & $(0.0007)$ \\
\hline \multicolumn{3}{|l|}{ PCI } \\
\hline \multirow[t]{2}{*}{$E U R$} & $0.1902^{* * *}$ & $0.1067^{* * *}$ \\
\hline & $(0.0319)$ & $(0.0272)$ \\
\hline \multirow[t]{2}{*}{$C P I$} & $-0.0238^{* * *}$ & -0.0057 \\
\hline & $(0.0035)$ & $(0.0039)$ \\
\hline \multirow[t]{2}{*}{ CPIVol } & $-0.1078 * * *$ & $-0.0570 * * *$ \\
\hline & $(0.0229)$ & $(0.0148)$ \\
\hline \multirow[t]{2}{*}{ SizeFX } & 0.0007 & $0.0033^{* *}$ \\
\hline & $(0.0019)$ & $(0.0016)$ \\
\hline \multirow[t]{2}{*}{ XVoltoNOK } & -0.1796 & 0.2522 \\
\hline & $(0.3654)$ & $(0.2001)$ \\
\hline \multirow[t]{2}{*}{ WorldTrade } & $0.0793^{* * *}$ & 0.0051 \\
\hline & $(0.0143)$ & $(0.0207)$ \\
\hline \multirow[t]{2}{*}{ NorwayTrade } & $0.0182^{* * *}$ & 0.0088 \\
\hline & $(0.0013)$ & $(0.0072)$ \\
\hline \multirow[t]{2}{*}{ Diff } & $-0.0013^{* * *}$ & 0.0004 \\
\hline & $(0.0003)$ & $(0.0008)$ \\
\hline \multicolumn{3}{|l|}{ VCI } \\
\hline \multirow[t]{2}{*}{$E U R$} & $-0.1941^{* * *}$ & $-0.1220 * * *$ \\
\hline & $(0.0299)$ & $(0.0190)$ \\
\hline$C P I$ & $0.0094^{* * *}$ & 0.0028 \\
\hline & $(0.0014)$ & $(0.0015)$ \\
\hline CPIVol & $0.0446^{* * *}$ & $0.0204^{* * *}$ \\
\hline & $(0.0102)$ & $(0.0060)$ \\
\hline SizeFX & -0.0024 & 0.0000 \\
\hline & $(0.0018)$ & $(0.0011)$ \\
\hline$X$ VoltoNOK & $0.9587^{* * *}$ & -0.0189 \\
\hline & $(0.2452)$ & $(0.1230)$ \\
\hline WorldTrade & $0.0483^{* * *}$ & -0.0029 \\
\hline & $(0.0118)$ & $(0.0223)$ \\
\hline NorwayTrade & $-0.0291^{* * *}$ & -0.0055 \\
\hline & $(0.0015)$ & $(0.0101)$ \\
\hline Diff & $0.0005^{* * *}$ & -0.0010 \\
\hline & $(0.0002)$ & $(0.0006)$ \\
\hline Diagnostics & & \\
\hline Observations & 1,276 & 1,276 \\
\hline Log-Likelihood & $-1,189.94$ & $-1,088.97$ \\
\hline McFadden Pseudo $R^{2}$ & 0.15 & 0.22 \\
\hline
\end{tabular}

Notes: The dependent variable denotes currency share $j$ of country $n$ at time $t$. The

columns present the average marginal effects for country-specific variables only.

are reported in parentheses below the estimated average marginal effects. 


\section{Appendix}

This Appendix explains how our model fulfills the asymptotic properties of the score identity and derives the average marginal effects.

\section{A.1 Score Identity of Currency Shares}

We know from maximum likelihood theory that the expected value of the score at the true parameter value $\boldsymbol{\theta}$ is zero:

$$
\mathrm{E}_{0}\left[\mathbf{g}_{n t}(\boldsymbol{\theta})\right]=\mathbf{0},
$$

where the scores are given by:

$$
\mathbf{g}_{n t}(\boldsymbol{\theta})=\frac{\partial \ln \mathrm{S}_{n t}(\boldsymbol{\theta})}{\partial \boldsymbol{\theta}},
$$

and $\boldsymbol{\theta}$ is the parameter vector. The observation's score with respect to the currency-specific vector $\boldsymbol{\alpha}$ is:

$$
\frac{\partial \sum_{j=1}^{J} s_{j n t} \ln \hat{\mathrm{S}}_{j n t}}{\partial \boldsymbol{\alpha}}=\mathbf{Z}_{n t}^{\prime}\left(\boldsymbol{s}_{n t}-\hat{\mathrm{S}}_{n t}\right)
$$

where both vectors $s_{n t}$ and $\hat{\mathrm{S}}_{n t}$ have dimension $J \times 1$. The observation's score with respect to the country-specific vector $\boldsymbol{\beta}_{v}$ is:

$$
\frac{\partial \sum_{j=1}^{J} s_{j n t} \ln \hat{\mathrm{S}}_{j n t}}{\partial \boldsymbol{\beta}_{v}}=\mathbf{x}_{n t} \sum_{j=1}^{J_{v}}\left(s_{j n t}-\hat{\mathrm{S}}_{j n t}\right),
$$

where $J_{v}$ is the number of currencies in currency group $v$. Since $\mathbf{Z}_{n t}$ and $\mathbf{x}_{j n t}$ are non-zero,

equality A.1 only holds true when $s_{j n t}=\hat{\mathrm{S}}_{j n t}$ for all $j$. Note that the scores used by Papke and Wooldridge (1996) are a special case of equation A.4 with $J=2$ and no currency groups; that is, $\mathbf{x}_{j n t}\left(s_{j n t}-\hat{\mathrm{S}}_{j n t}\right)$.

\section{A.2 Average Marginal Effects}

This section derives the mathematical expressions underlying the average marginal effects, which are calculated in Tables 4 7. The marginal effect measures the effect of a change in the regressor on the conditional probability that a currency is chosen with unit probability. There 
are different ways to measure marginal effects because they vary with the point of evaluation. The most common form in the invoicing literature - and the international economics literature more generally - is marginal effects at the sample mean of the regressors (cf. Donnenfeld and Haug, 2008; Wilander, 2006). Alternatively, one could use average marginal effects, which are computed as means of marginal effects over all observations. Although marginal effects at the mean are an asymptotically valid approximation of average marginal effects (Greene, 1997, p. 876), the current econometric practice favors the latter. Papke and Wooldridge (2008) derive average marginal effects in the context of a binary fractional probit model. We propose average marginal effects to be used for our compositional multinomial logit model.

For currency-specific variables, the average marginal effect for currency group $v$ is calculated by averaging over the change in the predicted probability across countries and time periods:

$$
\frac{1}{N T} \sum_{n=1}^{N} \sum_{t=1}^{T} \frac{\partial \hat{\mathrm{S}}_{v n t}}{\partial z_{k n r t}},
$$

where

$$
\hat{\mathrm{S}}_{v n t}=\sum_{j=1}^{J_{v}} \hat{\mathrm{S}}_{j n t},
$$

is the predicted group share summed across the predicted currency shares in group $v$ with $J_{v}$ currencies. Equation A.5 shows the change in the share function of choosing currency group $v$ when the $r$ th currency-specific explanatory variable increases by one unit for currency group $k$ but does not change for the other currency groups. For country-specific variables, we find

$$
\frac{1}{N T} \sum_{n=1}^{N} \sum_{t=1}^{T} \frac{\partial \hat{\mathrm{S}}_{v n t}}{\partial x_{n r t}},
$$

which represents the change in the predicted share of currency group $v$ when the $r$ th countryspecific explanatory variable increases by one unit.

Because logit probabilities have closed-form solutions, the marginal effects for A.5 can be stated explicitly as:

$$
\frac{1}{N T} \sum_{n=1}^{N} \sum_{t=1}^{T} \hat{\mathrm{S}}_{v n t}\left(1-\hat{\mathrm{S}}_{k n t}\right) \hat{\beta}_{r},
$$


for $k=v$ and

$$
\frac{1}{N T} \sum_{n=1}^{N} \sum_{t=1}^{T}\left(-\hat{\mathrm{S}}_{v n t}\right) \hat{\mathrm{S}}_{k n t} \hat{\beta}_{r}
$$

for $k \neq v$.

In the case of dummy variables (denoted by $d$ ) such as $E U R_{j t}$ and Euro Control Ev $_{j t}$ the average marginal effect for currency-specific variables is calculated as:

$$
\frac{1}{N T} \sum_{n=1}^{N} \sum_{t=1}^{T}\left[\hat{\mathrm{S}}_{\text {vnt }}(\cdot \mid d=1)-\hat{\mathrm{S}}_{\text {unt }}(\cdot \mid d=0)\right],
$$

for $u=v$ and

$$
\frac{1}{N T} \sum_{n=1}^{N} \sum_{t=1}^{T}\left[\hat{\mathrm{S}}_{v n t}(\cdot \mid d=1)-\hat{\mathrm{S}}_{k n t}(\cdot \mid d=0)\right],
$$

for $k \neq v$. To arrive at the marginal effect of Euro Control $_{j t}$, we average across the transition period only. 
Table A.1: Data Description and Sources

\begin{tabular}{|c|c|c|}
\hline Variable & Description & Primary Source \\
\hline$s_{j n t}$ & $\begin{array}{l}\text { Fraction of Norwegian goods imports from partner } \\
\text { country } n \text { that is invoiced in currency } j \text { at time } t \text {. } \\
\text { The currency shares are calculated from aggregated } \\
\text { bilateral import values using equation (1) of the main } \\
\text { text. Because the bilateral import values }\left(m_{j n t}\right) \text { are } \\
\text { reported in the Norwegian krone (NOK), we apply } \\
\text { an exchange rate adjustment: } m_{j n t}^{A}=\frac{X_{j t}}{X_{j 1996}} m_{j n t}^{R} \text {, } \\
\text { where } X_{j t} \text { denotes the period average exchange rate } \\
\text { of currency } j \text { with respect to the Norwegian krone at } \\
\text { time } t \text { and the superscripts } A \text { and } R \text { denote adjusted } \\
\text { and reported, respectively. }\end{array}$ & $\begin{array}{l}\text { The currency shares are derived } \\
\text { from customs data provided by } \\
\text { Statistics Norway. The period } \\
\text { average exchange rates are } \\
\text { taken from the IMF's (2009) } \\
\text { International Financial } \\
\text { Statistics (IFS). }\end{array}$ \\
\hline$E U R_{n t}$ & $\begin{array}{l}\text { Dummy variable taking on a value of one from Jan- } \\
\text { uary } 1,1999 \text { onward if the partner country } n \text { is part } \\
\text { of the eurozone. }\end{array}$ & $\begin{array}{l}\text { European Central Bank (ECB) } \\
\text { http://www.ecb.int/ }\end{array}$ \\
\hline$E U R_{j t}$ & $\begin{array}{l}\text { Dummy variable taking on a value of one from Jan- } \\
\text { uary } 1,1999 \text { onward if the chosen currency } j \text { is part } \\
\text { of the eurozone (i.e., a legacy currency) or is the euro } \\
\text { itself. The legacy currencies are included up to De- } \\
\text { cember } 31,2001 \text {. }\end{array}$ & $\begin{array}{l}\text { ECB } \\
\text { http://www.ecb.int// }\end{array}$ \\
\hline Euro Control $_{j t}$ & $\begin{array}{l}\text { Dummy variable taking on a value of one if the cho- } \\
\text { sen currency } j \text { is one of the legacy currencies between } \\
\text { January } 1,1999 \text { and December } 31,2001 \text {. }\end{array}$ & $\begin{array}{l}\text { ECB } \\
\text { http://www.ecb.int// }\end{array}$ \\
\hline$C P I_{n t}$ & $\begin{array}{l}\text { Expected inflation rate of partner country } n \text { at time } \\
t \text { (in percent). Calculated as a 4-period moving av- } \\
\text { erage of the consumer price index (CPI) of country } \\
n .\end{array}$ & $\begin{array}{l}\text { IMF's IFS } \\
\text { http://www.imfstatistics.org/imf/ }\end{array}$ \\
\hline CPIVol $_{n t}$ & $\begin{array}{l}\text { Expected inflation volatility of partner country } n \text { at } \\
\text { time } t \text {. Calculated as the standard deviation of the } \\
\text { CPI of the four preceding quarters. }\end{array}$ & $\begin{array}{l}\text { IMF's IFS } \\
\text { http://www.imfstatistics.org/imf/ }\end{array}$ \\
\hline $\mathrm{CPIVol}_{j t}$ & $\begin{array}{l}\text { Expected inflation volatility of partner country } n \text { or } \\
\text { country group using currency } j \text { at time } t \text {. Calculated } \\
\text { as the standard deviation of the CPI of the four pre- } \\
\text { ceding quarters. }\end{array}$ & $\begin{array}{l}\text { IMF's IFS } \\
\text { http://www.imfstatistics.org/imf/ }\end{array}$ \\
\hline
\end{tabular}


Table A.1: Data Description and Sources (Continued)

\begin{tabular}{|c|c|c|}
\hline Variable & Description & Primary Source \\
\hline $\operatorname{SizeFX}_{n t}$ & $\begin{array}{l}\text { Depth of the foreign exchange market of the currency } \\
\text { of country } n \text { at time } t \text {. Calculated based on the Tri- } \\
\text { ennial Central Bank Survey: Foreign Exchange and } \\
\text { Derivatives Market Activity conducted by the Bank } \\
\text { for International Settlements (BIS). The survey re- } \\
\text { ports the currency distribution of foreign exchange } \\
\text { market turnover during a given day. A 3-year mov- } \\
\text { ing average of fractions of the individual currencies } \\
\text { is used to determine the foreign exchange market } \\
\text { depth. Surveys relevant to our study were conducted } \\
\text { in } 1995,1998,2001,2004 \text {, and } 2007 \text {. Missing years } \\
\text { were interpolated. }\end{array}$ & $\begin{array}{l}\text { BIS (2007) } \\
\text { http://www.bis.org/statistics }\end{array}$ \\
\hline $\operatorname{SizeFX}_{j t}$ & $\begin{array}{l}\text { Depth of the foreign exchange market of currency } j \\
\text { at time } t \text {. See above. }\end{array}$ & $\begin{array}{l}\text { BIS (2007) } \\
\text { http://www.bis.org/statistics }\end{array}$ \\
\hline$X$ VoltoNOK $_{n t}$ & $\begin{array}{l}\text { Expected volatility of the exchange rate of the Nor- } \\
\text { wegian krone (NOK) with respect to the currency } \\
\text { of country } n \text { time } t \text {. Calculated as the coefficient of } \\
\text { variation of the four preceding quarters. }\end{array}$ & $\begin{array}{l}\text { IMF's IFS } \\
\text { http://www.imfstatistics.org/imf/ }\end{array}$ \\
\hline$X$ VoltoNOK $_{j t}$ & $\begin{array}{l}\text { Expected volatility of the exchange rate of the Nor- } \\
\text { wegian krone (NOK) with respect to the chosen cur- } \\
\text { rency } j \text { at time } t \text {. Calculated as the coefficient of } \\
\text { variation of the four preceding quarters. }\end{array}$ & $\begin{array}{l}\text { IMF's IFS } \\
\text { http://www.imfstatistics.org/imf/ }\end{array}$ \\
\hline$X_{\text {VoltoPart }}$ jnt & $\begin{array}{l}\text { Expected volatility of the exchange rate of the pro- } \\
\text { ducer currency with respect to the chosen currency } \\
j \text { at time } t \text {. Calculated as the coefficient of variation } \\
\text { of the four preceding quarters. }\end{array}$ & $\begin{array}{l}\text { IMF's IFS } \\
\text { http://www.imfstatistics.org/imf/ }\end{array}$ \\
\hline WorldTrade $_{n t}$ & $\begin{array}{l}\text { World trade share of country } n \text { at time } t \text { (in percent). } \\
\text { Defined as the sum of the value of goods exports and } \\
\text { imports of country } n \text { divided by the sum of the value } \\
\text { of world exports and imports. }\end{array}$ & $\begin{array}{l}\text { OECD trade data } \\
\text { http://www.oecd.org/statsportal/ }\end{array}$ \\
\hline NorwayTrade $_{n t}$ & $\begin{array}{l}\text { Goods trade share of country } n \text { with Norway at time } \\
t \text { (in percent). Defined as the sum of country } n \text { 's } \\
\text { value of exports to and imports from Norway divided } \\
\text { by the sum of Norway's goods exports and imports. }\end{array}$ & $\begin{array}{l}\text { Statistics Norway } \\
\text { http://www.ssb.no/en// }\end{array}$ \\
\hline $\operatorname{Diff}_{n t}$ & $\begin{array}{l}\text { Share of differentiated goods in Norwegian imports } \\
\text { from country } n \text { in year } t \text { (in percent). Calculated as } \\
\text { the sum of imported goods that are classified (based } \\
\text { on SITC 4) to be differentiated by the conservative } \\
\text { specification of the Rauch-Index (cf. Rauch, 1999) } \\
\text { divided by total value of Norwegian imports in that } \\
\text { period. }\end{array}$ & Statistics Norway \\
\hline
\end{tabular}


Table A.2: Descriptive Statistics

\begin{tabular}{|c|c|c|c|c|c|}
\hline & Obs & Mean & St. dev & Min & Max \\
\hline \multicolumn{6}{|l|}{ Currency shares } \\
\hline Norwegian krone & 1,276 & 0.3544 & 0.1577 & 0.0149 & 0.7995 \\
\hline Australian dollar & 1,276 & 0.0033 & 0.0183 & 0 & 0.2016 \\
\hline Canadian dollar & 1,276 & 0.0261 & 0.1387 & 0 & 0.8704 \\
\hline Czech koruna & 1,276 & 0.0003 & 0.0018 & 0 & 0.0204 \\
\hline Danish krone & 1,276 & 0.0280 & 0.0822 & 0 & 0.5354 \\
\hline Hungarian forint & 1,276 & 0 & 0 & 0 & 0 \\
\hline Iceland krona & 1,276 & 0.0006 & 0.0040 & 0 & 0.0650 \\
\hline Japanese yen & 1,276 & 0.0078 & 0.0423 & 0 & 0.4854 \\
\hline Mexican peso & 1,276 & 0 & 0 & 0 & 0 \\
\hline New Zealand dollar & 1,276 & 0.0027 & 0.0169 & 0 & 0.2421 \\
\hline Polish zloty & 1,276 & 0.0006 & 0.0051 & 0 & 0.0768 \\
\hline Pound sterling & 1,276 & 0.0253 & 0.0826 & 0 & 0.5633 \\
\hline Slovak koruna & 1,276 & 0 & 0 & 0 & 0 \\
\hline South Korean won & 1,276 & 0 & 0 & 0 & 0 \\
\hline Swedish krona & 1,276 & 0.0401 & 0.0823 & 0 & 0.5091 \\
\hline Swiss franc & 1,276 & 0.0174 & 0.0878 & 0 & 0.6890 \\
\hline Turkish lira & 1,276 & 0 & 0 & 0 & 0 \\
\hline US dollar & 1,276 & 0.1680 & 0.1982 & 0 & 0.8949 \\
\hline Euro & 928 & 0.2090 & 0.2317 & 0 & 0.9260 \\
\hline Austrian schilling & 725 & 0.0084 & 0.0556 & 0 & 0.5914 \\
\hline Belgian franc & 725 & 0.0062 & 0.0326 & 0 & 0.2851 \\
\hline Dutch guilder & 725 & 0.0110 & 0.0533 & 0 & 0.4871 \\
\hline Finnish mark & 725 & 0.0032 & 0.0230 & 0 & 0.2577 \\
\hline French franc & 725 & 0.0086 & 0.0573 & 0 & 0.5321 \\
\hline German mark & 725 & 0.0616 & 0.1159 & 0 & 0.7612 \\
\hline Greek drachma & 725 & 0.0011 & 0.0112 & 0 & 0.1685 \\
\hline Irish pound & 725 & 0.0011 & 0.0087 & 0 & 0.1568 \\
\hline Italian lira & 725 & 0.0072 & 0.0498 & 0 & 0.4651 \\
\hline Luxembourg franc & 725 & 0.0008 & 0.0082 & 0 & 0.1530 \\
\hline Portuguese escudo & 725 & 0.0011 & 0.0079 & 0 & 0.0879 \\
\hline Spanish peseta & 725 & 0.0049 & 0.0356 & 0 & 0.3293 \\
\hline $\mathrm{ECU}$ & 348 & 0.0011 & 0.0048 & 0 & 0.0643 \\
\hline \multicolumn{6}{|l|}{ Explanatory variables } \\
\hline$E U R_{n t}$ & 1,276 & 0.2955 & 0.4564 & 0 & 1.0000 \\
\hline$E U R_{j t}$ & 1,276 & 0.1585 & 0.3652 & 0 & 1.0000 \\
\hline EuroControl $_{j t}$ & 1,276 & 0.1303 & 0.3366 & 0 & 1.0000 \\
\hline$C P I_{n t}$ & 1,276 & 5.1098 & 11.2552 & -1.0076 & 93.7205 \\
\hline$C P I_{j t}$ & 1,276 & 5.4667 & 11.8765 & -1.0076 & 93.7205 \\
\hline CPIVol $_{n t}$ & 1,276 & 0.7962 & 1.6186 & 0.0331 & 21.5883 \\
\hline SizeFX $_{n t}$ & 1,276 & 8.3405 & 10.4873 & 0.0100 & 45.1500 \\
\hline SizeFX $X_{j t}$ & 1,276 & 3.6759 & 8.9979 & 0 & 45.1500 \\
\hline$X$ VoltoNOK $_{n t}$ & 1,276 & 0.0304 & 0.0297 & 0.0015 & 0.3326 \\
\hline$X$ VoltoNOK $_{j t}$ & 1,276 & 0.0300 & 0.0317 & 0 & 0.3326 \\
\hline XVoltoPart jnt $_{\text {jol }}$ & 1,276 & 0.0367 & 0.0408 & 0 & 0.3684 \\
\hline WorldTrade $_{n t}$ & 1,276 & 0.7273 & 0.8840 & 0.0082 & 4.4337 \\
\hline NorwayTrade $_{n t}$ & 1,276 & 2.9284 & 3.6811 & 0.0293 & 15.5398 \\
\hline $\operatorname{Diff}_{n t}$ & 1,276 & 74.1243 & 20.7023 & 11.7460 & 99.0010 \\
\hline
\end{tabular}

Notes: The variables are described in Table A.1. 


\section{References}

Anderson, J. E. (1979): "A Theoretical Foundation for the Gravity Equation," American Economic Review, 69, 106-116.

Andrews, D. K. (1993): “Tests for Parameter Instability and Strutural Change With Unknown Change Point," Econometrica, 61, 821-856.

Bacchetta, P., and E. Van Wincoop (2005): "A Theory of Currency Denomination in International Trade," Journal of International Economics, 67, 295-319.

Bank for International Settlements (2007): Triennial Central Bank Survey: Foreign Exchange and Derivatives Market Activity. Bank for International Settlements, Basel.

Baron, D. P. (1976): "Fluctuating Exchange Rates and the Pricing of Exports," Economic Inquiry, 14, 425-438.

Berry, S. T. (1994): "Estimating Discrete-Choice Models of Product Differentiation," RAND Journal of Economics, 25, 242-262.

Betts, C., And M. B. Devereux (2000): "Exchange Rate Dynamics in a Model of Pricingto-Market," Journal of International Economics, 50, 215-244.

Borsum, O., and B. A. OdegaArd (2005): "Currency Hedging in Norwegian Non-Financial Firms," Discussion paper, Norwegian Central Bank, Norway.

Cameron, A. C., J. B. Gelbach, and D. L. Miller (2008): "Bootstrap-Based Improvements for Inference with Clustered Errors," Review of Economics and Statistics, 90, $414-427$

Cornell, B. (1980): "The Denomination of Foreign Trade Contracts Once Again," Journal of Financial and Quantitative Analysis, 15, 933-944.

Devereux, M. B., C. Engel, and P. E. StorgaArd (2004): "Endogenous Exchange Rate Pass-Through When Nominal Prices are Set in Advance," Journal of International Economics, 63, 263-291. 
Donnenfeld, S., And A. Haug (2003): "Currency Invoicing in International Trade: An Empirical Investigation," Review of International Economics, 11, 332-345.

_ (2008): "Currency Invoicing of US Imports," International Journal of Finance and Economics, 13, 184-198.

Donnenfeld, S., And I. Zilcha (1995): "Bargaining in International Trade under Exchange-Rate Uncertainty," Review of International Economics, 3, 249-263.

Feenstra, R., J. E. Gagnon, and M. Knetter (1996): "Market Share and Exchange Rate Pass-Through in World Automobile Trade," Journal of International Economics, 40, $187-207$.

Feenstra, R. C. (1989): "Symmetric Pass-Through of Tariffs and Exchange Rates under Imperfect Competition: An Empirical Test," Journal of International Economics, 27, 2545.

Fischer, A. M., M. Lutz, And M. WÄLti (2007): "Who Prices Locally? Survey Evidence of Swiss Exporters," CEPR Working Papers No. 6442, Center for Economic Policy Research, London.

Friberg, R., And F. Wilander (2008): "The Currency Denomination of Exports: A Questionnaire Study," Journal of International Economics, 75, 54-69.

GoldberG, L. S., And C. Tille (2008): "Vehicle Currency Use in International Trade," Journal of International Economics, 76, 177-192.

(2011): "Micro, Macro, and Strategic Forces in International Trade Invoicing," mimeo, Federal Reserve Bank of New York, New York.

Gopinath, G., O. Itskhoki, and R. Rigobon (2010): "Currency Choice and Exchange Rate Pass-Through," American Economic Review, 100, 304-36.

Grassman, S. (1973): "A Fundamental Symmetry in International Payment Patterns," Journal of International Economics, 3, 105-116. 
Greene, W. (1997): Econometric Analysis. Prentice Hall, Upper Saddle River, New Jersey, 3rd edn.

International Monetary Fund (2009): International Financial Statistics. International Monetary Fund, Wahington, D.C.

Ito, T., S. Koibuchi, K. Sato, and J. Shimizu (2010): "Why Has the Yen Failed to Become a Dominant Invoicing Currency in Asia? A Firm-Level Analysis of Japanese Exporters' Invoicing Behavior," NBER Working Papers No. 16231, National Bureau of Economic Research, Cambridge, MA.

Kamps, A. (2006): "The Euro as Invoicing Currency in International Trade," Working Paper No. 665, European Central Bank, Frankfurt.

KInG, G. (1997): A Solution to the Ecological Inference Problem, Reconstructing Individual Behaviour from Aggregate Data. Princeton University Press, Princeton.

Krugman, P. R. (1980): "Vehicle Currencies and the Structure of International Exchange," Journal of Money, Credit, and Banking, 12, 513-526.

(1987): "Pricing-to-Market When the Exchange Rate Changes," in Real Financial Linkages Among Open Economies, ed. by S. Arndt, and J. Richardson, pp. 60-72. MIT Press, Massachusetts.

Ligthart, J. E., AND J. DA Silva (2007): "Currency Invoicing in International Trade: A Panel Data Approach,” Working Paper No. 2007-25, Tilburg University, Tilburg.

Ligthart, J. E., And S. E. V. Werner (2011): "Web Appendix: Has the Euro Affected the Choice of Invoicing Currency?," Mimeo, Tilburg University. Download from: http://www.tilburguniversity.edu/webwijs/files/center/ligthart/invoicingWA.pdf.

Magee, S. P., and R. K. S. RaO (1980): "Vehicle and Nonvehicle Currencies in International Trade," American Economic Review, 70, 368-373.

McKinnon, R. I. (1979): Money in International Exchange: The Convertible Currency System. Oxford University Press, Oxford. 
Melvin, M., and J. Sultan (1990): "The Choice of an Invoicing Currency in International Trade and the Balance of Trade Impact of Currency Depreciation," Open Economies Review, 1, 251-268.

Nevo, A. (2001): "Measuring Market Power in the Ready-to-Eat Cereal Industry," Econometrica, 69, 307-342.

Obstfeld, M., And K. Rogoff (1995): "Exchange Rate Dynamics Redux," Journal of Political Economy, 103, 624-660.

Papke, L. E., And J. M. Wooldridge (1996): "Econometric Methods for Fractional Response Variables with an Application to 401(k) Plan Participation Rates," Journal of Applied Econometrics, 11, 619-632.

(2008): "Panel Data Methods for Fractional Response Variables with an Application to Test Pass Rates," Journal of Econometrics, 145, 121-133.

RAUCH, J. E. (1999): "Network Versus Markets in International Trade," Journal of International Economics, 48, 7-35.

Swoboda, A. K. (1968): "The Euro-Dollar Market: An Interpretation," Essays in International Finance 181, Princeton University, Princeton.

Viaene, J.-M., and C. G. De Vries (1992): "On the Design of Invoicing Practices in International Trade," Open Economies Review, 3, 133-142.

Wilander, F. (2006): "An Empirical Analysis of the Currency Denomination in International Trade," mimeo, Stockholm School of Economics, Stockholm. 